\title{
A Forgotten Chapter in South Asian Book History? A Bird's Eye View of Sanskrit Print Culture
}

\author{
Camillo A. Formigatti
}

idaṃ mañjuśrīs tathāgatasya nāmāṣṭottaraśatakaṃ ye kecil likhiṣyanti likhāpayiṣyanti pustakagatam api kṛtvā g̣̣he dhārayiṣyanti vācayiṣyanti | te parikṣin̄āyuṣah punar eva varṣaśatāyuṣo bhavișyanti | itaś cyutvā aparimitāyuṣas tathāgatasya buddhakṣetre upapadyante | aparimitāyuṣaś ca bhaviṣyanti aparimitāguṇasañcayāyāṃ lokadhātau |

Mañjuśrī, those who will copy this collection of one-hundred and eight names of the Tathāgata, will commission it to be copied, and after having committed it to a book, will keep it at home, will recite it, once their life is exhausted, they will become again endowed with a life-span of a hundred years. Once they have left this world, they enter the Pure Land of the Buddha of the Infinite Life, and will have an infinite life in the Realm with the Infinite Multitude of Qualities.

Aparimitayurjñānanāmamahāyānasūtra (WALLESER 1916, 22)

pustakasthā tu yā vidyā parahaste ca yad dhanam | kāryakāle samutpanne na sā vidyā na tad dhanam ||

Knowledge stored in a book and money in the hand of others:

When the time to act has come, there are neither knowledge nor money!

Cānakyaniti 678 (STERNBACH 1967, 413)

When I was asked to talk about Sanskrit print culture in the workshop Printing as an Agent of Change in Tibet and Beyond, I enthusiastically accepted. Unfortunately, I didn't have the slightest idea of what I was getting myself

(C) CAMillo A. FORMigATti, 2016 | DOI 10.1163/9789004316256_008

This is an open access chapter distributed under the terms of the Creative Commons Attribution-

Noncommercial 3.0 Unported (CC-BY-NC 3.0) License. 
into. ${ }^{1}$ I was just glad that somebody had finally accepted the challenge issued by Elizabeth Eisenstein in the first edition of her book The Printing Press as an Agent of Change:

As noted in my preface, the term 'print culture' is used to refer only to postGutenberg developments in the West. How printing affected pre-Gutenberg Asia must be left to others to investigate. (Eisenstein 1979, 9, fn. 18)

However, soon I realized that I might have made a big mistake by accepting such a challenge: virtually all studies on South Asian print culture focus on printing of vernacular texts. To my knowledge, there is no comprehensive study of the printing of Sanskrit texts, a fact reflected for instance in the recent volume The History of the Book in South Asia (Orsini 2013), a very interesting and useful collection of essays dealing with many aspects of South Asian book history, enriched by a thoughtful introduction. It is divided into four parts: 1. "Writing, Orality and the Manuscript Book," 2. "Technology and Practices" (i.e. print culture), 3. "The Cultures of the Book in Colonial India" and finally 4. "Post-Colonial Histories." Yet, even in this rich vademecum, the printing of Sanskrit works is not dealt with in any essay: all contributions included in Part II focus on the print of vernacular texts (Hindi, Urdu, Tamil etc.).

\section{Introduction, or Arbitrary Definitions of Sanskrit Printed Works}

Even though I share Carlo Cipolla's opinion that "the surest way to fail as an author is to start by sounding pedantic, and the surest way to sound pedantic is to start with an unexhilarating search for definitions" (Cipolla 1969, 11), I am afraid I will have to start my article with a definition. I beg the readers' forgiveness. Many contributions in this volume deal with geographically defined

1 I would like to express my gratitude to all colleagues and friends who helped me in many ways while I was writing this article. First and foremost, I thank the editors of the volume for their patience, and above all Dr Hildegard Diemberger (Cambridge), who contributed also with suggestions about the role of print in Tibet and Nepal. Many thanks go also to Dr Michela Clemente (Cambridge), who read parts of the draft and discussed with me some of the ideas presented. A first draft of the article was presented at the Centre for the Study of Manuscript Cultures of the University of Hamburg, where I profited very much from the lively discussion that followed - above all, I would like to thank Dr Martin Delhey (Hamburg), whose remarks helped me honing the definition of Sanskrit print. I owe thanks also to Prof. Dr Stefano Zacchetti (Oxford), who pointed to my attention the article by J.-P. Drège about the Dunhuang prints. Dr Lore Sander kindly helped me by providing bibliographical information about studies of the Turfan Sanskrit blockprints. 
printing traditions (like Mongolian, Chinese, and Tibetan printing traditions, or the intersection between all these traditions). However, providing a clearcut definition of Sanskrit print culture is not an easy task. The material to be examined is defined according to a linguistic criterion, a fact bearing important consequences on the research approach. First of all, in order to delimit the field, we have to answer the apparently simple question: what are Sanskrit printed works? With the spread of Buddhism from the Indian subcontinent, Sanskritic culture as well moved northwards, crossing the Himalayan range to reach Central and East Asia. Scholars usually consider the numerous fragments of Sanskrit manuscripts found in the city-states and Buddhist monasteries in Central Asia along the Silk Road as belonging to South Asian manuscript culture. D. Wujastyk's remarks about the difficulty of finding a restrictive definition of Indian manuscripts can be applied, mutatis mutandis, also to Sanskrit prints:

What, then, really defines an "Indian manuscript?" For most specialists, this expression conjures up the idea of a handwritten document inscribed on paper or palm leaf, in Devanāgari or one of the other alphabets of South or Central Asia, and typically in the Sanskrit, Tamil or Persian language. But one has to bear in mind that the boundaries of definition are fluid, and that a manuscript from China, written on birch bark in the Kharoșțī script of Gandhāra and the Middle-Iranian language called Khotanese, may also be considered, in many respects, an Indian manuscript, for example if it contains a translation of a Sanskrit treatise on Buddhism or Āyurveda, or if it was produced in a Buddhist monastery that still had living links with India. (Wujastyk 2014, 159)

In other words, should we consider Sanskrit works printed in Central Asia as part of the history of Sanskrit printing? For the moment, let us answer this question in the positive and include in our survey all Sanskrit works printed in the Asian continent. Immediately, another question arises: what if the first attestation of the printing of Sanskrit works occurred outside the Asian continent? Should an evaluation of Sanskrit works printed and distributed, for instance, only in Europe, be included in this article? Moreover, since we are now applying a purely linguistic criterion, we might ask ourselves if we should take into consideration all printed works that contain some form of Sanskrit text. ${ }^{2}$ Some practical examples might help clarify this last point.

2 Even if the distinction between text and work applied in this article is rather intuitive, I hope it will prove helpful for the reader. It is based on C. Segre's definition of text: "The text is the 
The Bodhisattvāvadānakalpalatā (Av-klp) is a work composed in the style of kārya by the Kashmiri poet Kșemendra in the 11th century. Between 1260 and 1280 it was translated into Tibetan by the lo tsā ba Shong ston Rdo rje rgyal mtshan and the Pandit Lakșmīkara on behalf of Qubilai Khan's advisor's'Phags pa Blo gros rgyal mtshan. Thanks to this translation it enjoyed great popularity in Tibet, becoming a milestone of literary style as well as a source of inspiration for visual artists. In fact, this popularity is the reason why this work survived, for it is transmitted in its entirety only in a Tibetan bilingual edition containing the original Sanskrit together with the Tibetan translation, revised and printed in 1664-65 under the aegis of the Fifth Dalai Lama (on this edition are based also the canonical bilingual editions printed in the Derge and Cone Tanjur). ${ }^{3}$ Should we include in our survey these prints as well? Moreover, if we were to push the argument further, we might even ask ourselves if it is worth including Chinese and Japanese Buddhist prints containing Sanskrit dhāran̄is embedded in the main text, or even Japanese facsimile editions of Sanskrit texts.

At this stage, let us apply a purely linguistic criterion, and define Sanskrit prints as follows: either as (1) any print containing any kind of Sanskrit text, regardless of the completeness or length of the text, or (2) any print containing a complete Sanskrit work, regardless of other features (such as the presence of a translation in another language). It is immediately clear that the first definition is too broad, allowing us to include in the present analysis for instance the Japanese Hyakumantō darani prints, commissioned by the Empress Shotoku between $764-$ 770 - after all, even if this version of the dhäranī is written in Chinese characters, 'the texts consist almost entirely of sounds transcribed phonetically from the original Sanskrit' (Gardner 1993, 196). These kind of texts are beyond the scope of this article. The second definition is more restrictive, and would allow us to include in our survey the bilingual editions of Kșemendra's Bodhisattvāvadānakalpalatā. However, this printed work arguably belongs to Tibetan print culture, and it is of little help (if at all) in the reconstruction of the history of Sanskrit print culture.

linguistic texture of a discourse. In the meaning most prominent until the present century [Segre writes in the 2oth century], it is a written discourse (whose oral utterance cannot be defined as text anymore). When we speak of the text of a work, we point to the linguistic texture of which the work is formed; on the other hand, if we are referring to the content, work and text are almost identical" (emphasis mine; the original Italian is as follows: "Il testo è dunque il tessuto linguistico di un discorso. Nell'accezione prevalsa fino a questo secolo, si tratta di discorso scritto (la cui realizzazione vocale non è più denominabile come testo). Quando si parla del testo di un'opera, si indica il tessuto linguistico del discorso che la costituisce; se viceversa si allude al contenuto, opera e testo sono pressoché identici." Segre [2014, p. 298]).

3 On the 1664-65 edition, cf. Mejor 1992, 52-64; on the Tibetan transmission of the Av-klp, cf. also Straube 2006, 70-72 and 90-92; and Straube 2009, 18-22. 
The Sanskrit text is written in a Tibetan $d b u$ can script adapted to represent the Sanskrit language. This printed edition was conceived and produced within the Tibetan cultural sphere, where it also circulated, and thus had little impact on South Asian cultural history. This remark is proved by the fact that the first part of the Sanskrit original of the Bodhisattvāvadānakalpalatā was lost in South Asia, and all Nepalese manuscripts that have come down to us contain only avadānas from the second half of the work. ${ }^{4}$ Remarkably, the first part of the work was considered to be lost in Nepal, even if the complete work was still extant in the neighboring country of Tibet.

This last consideration introduces a geographical and cultural criterion that apparently allows us to narrow the scope of our survey. We might define Sanskrit prints as (3) any print containing a complete Sanskrit work, regardless of other features (such as the presence of a translation in another language), and printed in South Asia. At first sight, this last definition might appear fitting. On the other hand, if we were to apply it blindly, we would be forced to exclude any Sanskrit work printed outside South Asia, thus obliterating aspects and phenomena important for the scope of the present volume, i.e. an assessment of print culture in Asia. Moreover, it would exclude also short, fragmentary or incomplete texts, such as dhäranīs extracted from longer works. It is perhaps advisable to revise it, as we want to consider as many aspects as possible before pinning down a definition. Surely another aspect that should be added to the discussion is the printing technique. In an article on the history of lithography in India, G. Shaw describes its introduction in the South Asian continent, mentioning reports that circulated in India in the late 1820 s about a "form of lithography" that had originated in Asia:

A Dr J. G. Gerard of Sabathu, at a military post near Simla, mentioned meeting the famous Hungarian orientalist, Csomo [sic] de Körös, at the monastery of Kanam in Kunawar, whose learned companion, the Lama, has informed him that lithographic printing has flourished for ages in the ancient cities of Teshoo Loompoo and Lahassa', and the report of the proceedings of the Asiatic Society of Bengal for July 1829 recorded the presentation by the same Dr Gerard of 'a specimen of the stone used for lithographic printing in Thibet, and of the printing', a footnote adding that 'it seemed to be a fine-grained chlorito-argillaceous schist'. This is clearly a reference to the practice (originating in China but spreading early to other Buddhist cultures) of taking inked rubbings on paper from

4 On the textual transmission of the Sanskrit text of the Av-klp, see Straube 2006, 60-87; and Straube 2009, $3^{-17}$. 
stone inscriptions, the forerunner of taking impressions from wood, a process which the Sinologist Thomas F. Carter himself referred to in the 1920's as 'lithography' or 'lithograph rubbing'. (Shaw 1998, 91)

Despite Carter's definition of the inked rubbings on paper from stone inscriptions as 'lithography,' lithographic printing as it is commonly understood is based on a different technique, developed in Europe at the very end of the 18th century. Still, this passage is a good starting point for yet another question to be asked: which typology of printing technique is to be included in our definition? Reproduction techniques akin to printing were known in South Asia already from a very early age, such as impressing on clay tablets short texts like dhäranīs by means of sealings (the first specimens of this type of impressions are possibly dated to the first century BCE). Such texts were mechanically reproduced in a high number of identical items (one of the defining characteristics of printed texts), but were not meant to be read, their reproduction had, rather, a cultural and ritual purpose. ${ }^{5}$ Even though they can be considered to be the very first attestation of printing in South Asia, surprisingly little attention has been paid to them, perhaps because their primary function was magical and protective, and they were considered to be devoid of the transformative power attributed to texts printed in order to be read. ${ }^{6}$

It is possible to further narrow down the definition by combining the four criteria considered above (linguistic, geographical/cultural, grammatological ${ }^{7}$ and technological), and propose the following stricter definition: a Sanskrit print is (4) any object (complete or fragmentary) containing a Sanskrit text, printed in Asia in a South Asian script, ${ }^{8}$ with the purpose of being distributed

5 For a brief survey on this topic, see Kornicki 2012, 51ff.; on the dhāraṇīs impressed on clay tablets, see Lawson 1982.

6 "After all, these clay tablets with impressions of a seal or stamp are evidence of the use of mechanical means for the mass production of texts which were not manufactured for the purpose of reading; once they had been produced and ritually used their fate was of little concern" (Kornicki 2012, 52).

7 I.e. relating to the writing system. As pointed out by P. T. Daniels, the study of writing systems per se, as an object of a defined academic field of study, is relatively recent: "[W]riting systems per se, the marks that record the languages of the documents produced by the civilizations, have absorbed the attention of only a very few linguists. No name for this field of study has even become widely accepted; "grammatology," proposed in the mid twentieth century, is better than most" (Daniels and Bright 1996, 1).

8 Again, this characteristic might be too broad, for it is possible to include under the label "South Asian" also the Tibetan script (in almost all its varieties), since it is derived from a 
either for reading or for ritual activities, regardless of other features (such as the presence of a translation or paratexts in other languages).

All four definitions of Sanskrit print proposed above are valid, but on account of the nature of the present volume, I will take the fourth definition as a starting point. The three main printing techniques that in the past were employed for printing Sanskrit texts in Asia are xylography, lithography and letterpress printing. In the following three sections, I will try and provide some general remarks, based on a few examples of texts printed with these three techniques. The last section will be devoted to preliminary conclusions about the history of South Asian print culture.

2 Sanskrit Xylographs

This survey does not aim at being exhaustive; it is rather a starting point and a means for a first appraisal of the general features of Sanskrit xylographs. Two main sites in Central Asia will be taken into consideration: Dunhuang and Turfan. The Sanskrit prints found in the first site have a more uniform character, and have already been the object of preliminary studies. On the other hand, the Turfan findings display more variety both in terms of content and codicological features, yet to my knowledge no specific study has been devoted to them. For this reason, I will focus more on the xylographs from Turfan.

\subsection{Dunhuang}

Among thenumerous Sanskrit fragments of manuscripts found in the Dunhuang caves, a small number of bilingual Sanskrit woodblock prints have come to light. They all contain various dhäran̄is (such as the Sarvatathāgatoṣnịșasitātapatradharan̄i, or the Mahāpratisāradhäraṇī), often together with other Chinese texts or at least with Chinese paratexts (such as the donor's colophon) printed on the margins. They are all printed on paper, and the script used to write the Sanskrit text is a kind of siddhamätrkā. The Sanskrit text is usually written around a central figure representing a deity or a Bodhisattva, and each print displays a very complicated decorative layout, for instance in the form of a mandala starting from the centre, with the text written as a round spiral around the central figure. Occasionally the text is continued on the four margins, forming an external frame around the internal spiral. ${ }^{9}$

North Indian script. However, taking into considerations the other three criteria, it should still be possible to reasonably narrow down the domain of Sanskrit print.

9 Four of these prints are described in WU 1984, 68-72, and in Drège 1999. 
Scholars devoted particular attention to a print of the Mahāpratisāradhāraṇi discovered in Szechwan in 1994, in a tomb in Chengdu "dated from the latter part of the Tang period" (Twitchett 1983, 18). The dhäraṇi is written in Sanskrit, but on the right margin a colophon in Chinese provides information about the printer, a certain "Pien in the Lung-chih ward of Ch'eng-tu city. From the names used for administrative units it must date from some time after 757 " (ibidem). Such an early date would mean that this print is either older or at least contemporary with the oldest known prints, such as the the Hyakumanto darani (764$770 \mathrm{CE}$ ), or the printed dhāraṇı discovered inside the Sokkat'ap stone pagoda of the Pulguksa temple in Kyongju in South Korea and traditionally dated before $75^{1} \mathrm{CE} .{ }^{10}$ However, based on a comparison of dated similar material recovered in Dunhuang, Jean-Pierre Drège has proposed the 1oth century as a more probable date for this print (and similar ones) (Drège 1999, 34-35).

These dhäranīs were printed in multiple exemplars, like the Mahāpratisāradhāraṇi, of which three exemplars are known, one in the Bibliothèque nationale de France (Pelliot sanscrit 2), one in the Musée Guimet (E0. 3639), and one in the British Museum (Stein painting 249, figure 6.1). Moreover, it is not clear if such dhâraṇis were all printed in Dunhuang, probably some of them circulated: for instance, a xylograph of a Sanskrit dhāranī kept in the Musée Guimet, MG. 17688, is strikingly different in style from other 1oth Sanskrit xylographs from Dunhuang, and may have been printed elsewhere (Drège 1999, 28-29). From the viewpoint of the codicological features as well as of the content, the ritual and protective purpose of such prints is clear. In a bilingual xylograph from the Pelliot collection in the musée Guimet (MG. 17689), the Chinese text states that the person who prints, copies and carries the dhārañ $\bar{\imath}$ will be freed from all bad and gross negligence acts, will be helped by all Tathāgatas, will be protected by all Bodhisattvas and Nāga kings, will avoid all calamities and brutalities, will escape the evil destinies, and will not be hurt by water, fire, thunder, lightning, poison or evil (Drège 1999, 29-30).

\subsection{Turfan}

Numerous fragments of Sanskrit blockprints have been recovered during the German expeditions in the Turfan oasis. They have been described and edited in several volumes of the Sanskrithandschriften aus den Turfanfunden (sнт), published in the series Verzeichnis der Orientalischen Handschriften in Deutschland (voHD). Unfortunately, a list of the xylographs recovered is provided only in the first volume, and the indexes to all other sHT volumes do

10 The date of this dhärañi is still disputed, for a discussion of the various hypotheses see Kornicki 2012, 47-50. 


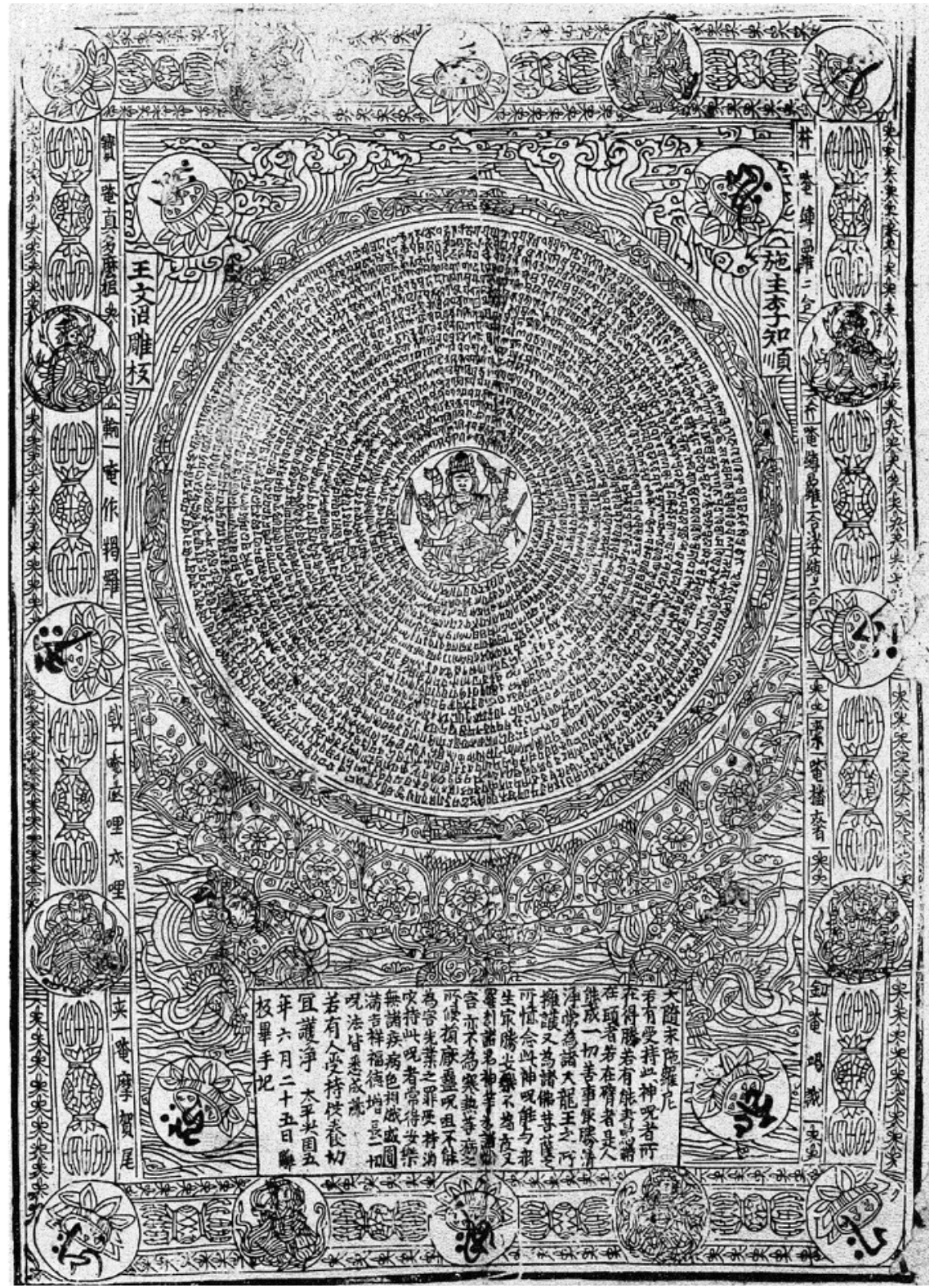

FIGURE 6.1 British Library, Stein painting 249. Ritual print with eight-armed figure surrounded by a dhāranī in Sanskrit, with the text of the Da sui qiu tuoluoni in Chinese. Northern Song dynasty, dated 5 th year of Taipingxingguo (AD 980). Xylograph, ink on paper with Sanskrit letters overprinted on the lotus medallions. Printed area: $H .41 .7 \mathrm{~cm}, W .30 .3 \mathrm{~cm}$. 
not help at all in the search for xylographs (they are organized according to topics and genre). In order to find them, I tried to use also the database of the International Dunhuang Project website, but its search functions are not very user friendly. Moreover, the 2011 electronic edition of the voHD volumes is still labelled as work in progress - it is probably for this reason that in the entries of the IDP online version of the catalogues, all xylographs are wrongly described as "manuscript, ink on paper." The following survey has thus been prepared by looking for xylographs in all entries in the eleven SHT volumes published until now. A list of the xylographs described in the SH T volumes is provided in Appendix A.

The very first observation is how scarcely represented Sanskrit xylographs are in the vast amount of book findings in the Central Asian city states. If we take into account the fragments of Sanskrit manuscripts so far catalogued in the voHD, and adjust this number by taking into consideration the possibility that some fragments described separately might actually belong to one single item, the proportion is staggering. In the eleven volumes I perused, a total of 5799 fragments are described, of which only nineteen are blockprints (much less than one per cent). One could be tempted to immediately draw the conclusion that although blockprinting technology was already known in Central Asia during the flourishing period of the city-states, it was scarcely used for Sanskrit texts. However, given the character of the material and the serendipity of the findings, I believe that any conclusion about the diffusion and impact of this printing technique for Sanskrit texts in Central Asia is highly hypothetical. Nonetheless, I also believe that it is worth trying to provide at least a preliminary assessment of the material. Needless to say, it has to be taken cum grano salis.

The xylographs are grouped according to three criteria: (1) location at which they were found, (2) script and (3) format and content. The reason why the last two aspects are subsumed under one criterion is that the relationship between format and content might yield useful information about the usage and function of the books..1

2.2.1

Distribution According to Location at which the Xylographs were Found

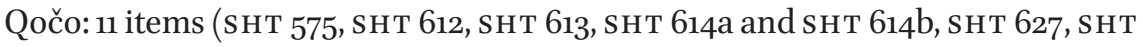
645, Sнт 646, sнт 1173, SHт 1191, sнт 1385).

Sängim: 2 items (SHT 1105, SHT 4352).

11 When fragment SHT 612 is mentioned in any of the following lists, it always includes SHT 1174 and SHT 5029; fragment SHT 1430 always includes SHT 4008, SHT 4015, SHT 4264, SHT 4524 b, SHT 4591 and sнt 647. 
Murtuq: 4 items (sHT 580, SHT 1110, SHT 1190, SHT 4442).

Unknown: 2 items (s

After more than forty years of research, the observation made by L. Sander in 1968 that most of the xylographs were found in Qočo is still valid (Sander 1968, $17 \mathrm{fn} 57$ ). Out of a total of nineteen fragments, eleven have been found in the temple city of Qočo. Strikingly, all other fragments have been found in two localities not far Qočo, Sängim and Murtuq. Unfortunately, the list of finding locations compiled during the German Turfan expeditions was lost during World War II, together with Theodor Bartus' diary, and assessing the provenance of the fragments with certainty is not always possible (Sander 1968, 7-8). Four sources for this task are listed by the German scholar: published reports of the expeditions, letters and documents in the archives about Turfan, seals on the fragments, and the extant lists of the findings (Sander 1968, 8). It is even more difficult to establish the exact place where each fragment was found within each complex of ruins. It is mainly thanks to the reports of the expeditions by Grünwedel and Le Coq that in some cases we have general gleanings on the precise locations of the findings. Fragments of manuscripts and xylographs were found in three types of locations: ruins of libraries, ruins of votive statues, and monks' cells. Still, more often than not it is impossible to assess with certainty whether a given fragment was recovered in a stūpa, in a votive statue or in a library. The following exemplary remark refers to the first expedition in Qočo, where the majority of the blockprints where recovered:

Über die Ergebnisse der ersten Expedition hat Grünwedel ausführlich berichtet. Er schildert auch eingehend die Handschriftenfunde, die er in den verschiedenen Ruinen gemacht hat, doch erwähnt er nicht, ob sie aus Bibliotheken oder Kultfiguren stammen könnten. Wahrscheinlich war diese Frage auch schwer zu beantworten, weil die Stadt gewaltsam zerstört worden ist und - wie alle anderen Fundstätten auch - laufend Plünderungen zum Opfer fiel. [...] Die anderen von der ersten Expedition aus Qočo mitgebrachten Bruchstücke von Sanskrithandschriften oder Blockdrucken sind wahrscheinlich käuflich erworben. Grünwedel konnte jedoch einen Teil der Fundorte von den Verkäufern ermitteln und sich durch Überprüfung der Angaben von ihrer Richtigkeit überzeugen. (Sander 1968, 16-17)

With regard to the other two cities, Sängim and Murtuq, we are left with the same degree of uncertainty. For instance, we can only speculate whether the two fragments found in Sängim, SHT 1105 (parts of a Deśanā) and SHT 4352 
(Sarvatathāgatoṣnūṣasitātapatradhāraṇī), come from a library or from another building. The last one for instance might have been found in the stüpas described by Le Coq. ${ }^{12}$ It is therefore an almost impossible task to put forward any tenable hypothesis as to the function of these xylographs based on their place of recovery.

1. Nordturkistanische Brāhmī, Typ b: SHT 575, SHT 580, sHT 612, sнT 613, SHT 614a, SHT 614b, SHT 627, SHT 1105, SHT 1110, SHT 1173, SH T 1190, SHT $1385^{*}$, SHT 1430, SHT 4442 .

2. Südturkistanische Brāhmī (Alphabet v): SHT 4352.

3. Pāla: sнt 645 , sн T 646.

Three different scripts were used for printing Sanskrit texts in the Turfan area. The first one is the "nordturkistanische Brāhmī", and as its name betrays, it was widely employed for the production of manuscripts in the regions on the northern route of the Silk road. According to L. Sander, on the basis of the ductus it is possible to further differentiate it into two types: "Typ a" was more widespread in the Kučā-Region, while "Typ b" was more so in the Turfan oasis (Sander 1968, 5). Since the xylographs were recovered in the Turfan region, it is no wonder that the script used in the great majority of the xylographs corresponds to the one used in manuscripts from the same area. The only exceptions are three fragments, sн т 645 , sнт 646 , and sнт 4352 . The latter is written in the südturkistanische Brāhmī (Alphabet v) used in the Khotan region (Sander 1968, 183), and contains part of the Sarvatathāgatoṣnịșasitātapatradhārañi, a text very popular and widespread in Central Asia. Given the character of this text, considered to be used in protective amulets, it may well be that this book had been produced elsewhere, and only later carried by a traveller to the place where it was found, Sängim.

12 "Trotz des abschreckenden Eindrucks dieser Landschaft ist die Schlucht auf ihrem linken oder westlichen Ufer mit einer Reihe von Tempeln besetzt, während die Höhen des rechten Ufers mit zahlreichen indischen Grabmonumenten (stūpa) besetzt sind, deren einige auch unmittelbar am rechten Ufer des Stromes sich erheben. Diese Stūpas enthielten Reste von Leichenbrand, künstliche Blumen, Votivgaben (Heiligenbilder auf Papier) und zahlreiche Manuskriptreste. Es muß auffallen, daß in einem dieser Denkmäler, in der Biegung des Stromes, ein nur wenig beschädigtes manichäisches Buchblatt, unter Bruchstücken zahlreicher buddhistischer indischer Handschriften, gefunden wurde. [...] Hier und da wurden auch Funde manichäischer und indischer Handschriften gemacht" (Le Coq 1926, 69-71). 
On the other hand, sHT 645 (figures 6.4 and 6.5) and sH 646 (figures 6.7 and 6.8) contain respectively parts of the Śatasāhasrikā Prajñāpāramitā and an unidentified dhärañi, and are written in a completely different type of script. L. Sander compares it to the so-called Tibetan sha-chen ("corpulent characters"), which is very similar to the Pāla script employed in Bengal during the Pāla dynasty, both in manuscripts as well as in inscriptions (Sander 1968). However, in the secondary literature the terminology for this type of script varies greatly, very often leading to a confusion with other very similar ornamental scripts probably derived from it. Cecil Bendall (and others after him) defined it as Kuțila (Bendall 1883, xxiv), but numerous other definitions have been applied, such as Nāgarī, Siddhamātrkā, Proto-bengali, Nevārī, and Rañjanā (Weissenborn 2012, 19). ${ }^{13}$ I prefer to adopt the term "Pāla" used by Sander, since it clearly indicates the geographical and cultural origin of this script. In her exhaustive palaeographical analysis of these two fragments, the German scholar already noticed that, on account of Buddhist missionary activity, the Pāla script rapidly spread to neighbouring countries such as Nepal and Tibet, spawning a series of similar, yet distinct scripts, including the sha-chen, (Sander 1968, 173-76). The use of the Pāla script or one of its derivatives was very often a sign of the particular prestige and/or ritual value attributed to a manuscript, and apparently was linked to specific texts: single dhäraṇis and collections thereof like the Pañcarakșā, Prajñäparamitā-texts (very often the Asțasahāsrikā), the Suvarnaprabhāsottamasūtra. ${ }^{14}$ The sacred and ornamental value of these scripts is testified to also by the fact that they were - and still are nowadays - used for writing Sanskrit titles on title pages of Tibetan manuscripts and prints, as well as for prayer-wheels and for inscriptions on sacred buildings. ${ }^{15}$ The script could give us also a clue as to the place of production of the xylographs: in the light of the fact that the Tibetan sha-chen is a modification of the Pāla script, L. Sander suggests that SHT 645 and SHT

13 The confusion goes even further, for instance the Rañjana and the Tibetan Lan-tsha are sometimes considered to be one and the same script - see for instance Tibetan and Mongolian abecedaria of Indian scripts, like the dByangs gsal bzhugs (Skt. Álikälibijahäram), composed by mGon po skyabs in the first half of the 18th century, but based on an older work written in 1586 AD (Chandra 1982, 3-5 and 9-14; on mGon po skyabs, see Wang-Toutain 2005).

14 Even a cursory analysis of catalogues of Buddhist manuscripts would confirm this remark.

15 See for instance the account provided by S. C. Das in 1888: "In the grand sanctuary of Sam-yea, Lan-tsha characters were written and painted and engraved on prayer cylinders, walls, tapestries, doors and chapels. On chaityas and votive piles there were numerous inscriptions written in the Lan-tsha character, which exist up to the present time round the central sanctuary of Sam-yea" (Das 1888, 44). 
646 were either produced in Tibet or carved in Qočo on the basis of Bengalese manuscripts (Sander 1968, 175-76). However, woodblock printing technology was already in use in China by the mid-seventh century, while the earliest extant xylograph from central Tibet is copy of Haribhadra's commentary on the Abhisamayālamkāra, produced in 1407 to commemorate the death of the ruler of Southern La stod Situ Chos kyi rin chen (died 1402).

\subsubsection{Distribution According to Format and Content}

1. Pothī: sHt 612 (Samyuktāgama), sHt 613 (Samyuktāgama), sHt 645 (Śatasāhasrikā Prajñāpāramitāa), SHT 1110 (unidentified Mahāyana text), SHT 1385* (Śatasāhasrikā Prajñāpāramitā?), sHT 1430 (Vinayavastu, Samghabhedavastu), sHT 4442 (unidentified text).

2. Accordion book: SHT 575 (Deśanā), sHT 580 (Catuṣpariṣatsūtra), sHT 627 (Stotras), sH 1173 (end of a colophon and ye dharmā formula), sHT 1190 (Sitātapatrahṛdayamantra), sHT $435^{2}$ (Sarvatathāgatoṣn̄ịsasitātapatradhāraṇī).

3. Scroll: SHT 1105 (Chinese characters on the recto, and on the verso a metrical Deśanā).

4. Unknown format (codex?): SHT 614a (Smrtyupasthāna), sHT 614b (Smṛtyupasthāna),sHT646(Dhāraṇī),s HT1191(Sarvatathāgatoṣṇiṣavijayanāmadhārañi), sHT $4465 \mathrm{v})$.

The range of book formats and the content of the fragments enable us to draw more plausible hypotheses about the function of these xylographs. From the viewpoint of the content, an interesting feature is that the findings include only few specific typologies of texts: (1) different sections of Sanskrit Buddhist canons (two fragments from the Samyuktāgama, two belonging to the Vinayavastu); (2) the Prajñāpāramitā literature (represented here in his version in 100,000 stanzas); (3) ritual and performative texts (two fragments of a Deśanā, two fragments of the Smrtyupasthāna, one fragment of the Catuṣparișatsūtra, and one fragment containing several stotras); (4) magical and protective spells (at least four fragments of various dhäraniss). It is not by chance that specific formats correspond to specific typologies of texts. The pothi format of South Asian origin is used to print canonical texts and the Prajñāpäramitā, probably in an attempt to give a more prestigious status to the printed books by appealing to the South Asian traditional format. In the case of the two long fragments of the Prajñāpāramitā, the South Asian cultural influence is seen not only in the format, but also in the use of the Pâla script, as explained above. 
On the other hand, the accordion books contain almost exclusively ritual and magical texts (including SHT 627, a fragment containing various stotras; on the daily recitation of this type of texts, cf. Schlingloff $1955,8 \mathrm{ff}$.). Unlike in the case of the pothi, this format is easier to handle during the recitation, for it enables the reader to hold the book and flip the pages even with one hand, without the aid of any surface to put the book on.

The other represented formats are the scroll and probably the codex. The scroll format is typically Chinese, and in fact SH T 1105 is a fragment containing Chinese characters on the recto (in this particular case, a Chinese book was repurposed). The presence of the codex format is uncertain due to the state of conservation of the fragments. However, SHT 614a is better preserved, and its dimensions are $15 \mathrm{~cm} \times 15 \mathrm{~cm}$, pointing to a different format than the pothi. SHT 646 is in an even better state (figures 6.7 and 6.8$)$, and its dimension $(10.7 \mathrm{~cm} \times$ $6.5 \mathrm{~cm}$ ) points more decidedly towards the codex.

\subsubsection{First Appraisal of Sanskrit Xylographs from Turfan}

As we have seen, it is almost impossible to pinpoint the exact position of the fragments and to place them in a definite stratigraphy in the sites where they were recovered. For this reason, the identification of the type of script is very important as a means to date the fragments. Again, according to the palaeographical study of L. Sander, the lower limit is the 7 th century CE, and the upper limit might be the 14 th century $C E$ (Sander 1968, 46-47). This rather large range of seven centuries can be narrowed down further by considering other features. As with most of the fragments, SHT 612 was found in Qočo and contains running titles in Uighur on the margins. This evidence might allow us to set lower and upper limits for the production of this xylograph that most probably coincide with the period of Uighur occupation of this city (850-1250). An upper limit of around the 13th-14th century is confirmed also by SHT 645 . The Pâla script of this xylograph is dated by Sander to the 14th century on account of palaeographical features and general considerations about the transmission of this script from Bengal to Tibet and Central Asia (Sander 1968, 176-77). However, manuscripts in this script were produced in Nepal already in the 12th century, ${ }^{16}$ and it is not an impossible scenario that manuscripts written in this script had reached the cities on the Silk Road already by the $13^{\text {th }}$ century. ${ }^{17}$ This

16 For instance, Add.1693 in the Cambridge University Library, a manuscript of the Aștasahāsrikā Prajñāparamitā, completed on Sunday, July 18th, 1165 CE in the Dharmacakra-vihāra in Kathmandu.

17 A confirmation of this hypothesis might be found in the running marginal titles in Chinese characters, to be dated after the 1oth century (Imre Galambos, personal communication). 
hypothesis coincides with the evidence at our disposal about the introduction of blockprinting in the Uighur kingdom of Qočo in the 13th-14th century.18 According to Annemarie von Gabain, four types of format where used for the production of manuscripts and xylographs in the Turfan area: codex, pothi, scroll, and accordion book. The accordion book format was a late introduction of the Uighurs, an aspect that might confirm the dating of the Sanskrit blockprints in this format to the last period of the Uighur occupation of the Turfan area (Gabain 1964, 173-76; 1967, 18-19).

Even though the range of items taken into consideration is very limited, a combination of the three criteria employed to group the xylographs, together with an analysis of their codicological features allows us to draw at least hypotheses about the production, use and diffusion of Sanskrit prints in the Turfan area. As noted above, the script employed in the great majority of them is the "nordturkistanische Brāhmī, Typ b" found in manuscripts from Turfan, a strong argument towards the hypothesis of the presence of local printeries. Following this line of reasoning, we can narrow the spectrum of possibilities and try to tentatively locate the printeries. Only two fragments were recovered in Sängim, SHT 1105 and SHT 4352. The first one is part of a scroll with five lines of Chinese on the recto, and a metrical Deśana on the verso. The scroll format and the Chinese characters are features pointing to the Chinese origin of this fragment, which has probably been re-used to print the Sanskrit text on the verso. SHT $435^{2}$ is written in "südturkistanische Brāhmī (Alphabet v)," a script mostly used in the Khotan region, and given the character of the text it contains (a protective spell), it might have been an amulet carried by a person coming from the southern route of the Silk Road. Among the four fragments found in Murtuq (sHT 580, SHT 1110, SHT 1190, SHT 4442), SHT 580 is part of an accordion book containing the Catușparișatsūtra. SHT 1110 consists of small fragments from the middle of a folio of an unidentified Mahāyana text; the format has been tentatively identified as pothī, but it might have been an accordion book as well. SHT 1190 is one folio of an accordion book containing the end of the Sitātapatrahrdayamantra with the title used as final rubric (and, as to be expected, parts of the ye dharmā formula). Finally, SH T 4442 consists of various fragments of a pothi containing a yet unidentified text. The accordion books were probably used for ritual purposes, but unfortunately we cannot make any hypothesis about the function of the pothi, since the text is unidentified. Nonetheless, we could assume that according to the type of texts and formats of the xylographs found in Murtuq, these prints might have been brought there for use, rather than produced in situ. On the other hand, eleven 
fragments - more than half of the total findings - were recovered in the temple-city of Qočo. Among these fragments all type of formats ${ }^{19}$ and texts ${ }^{20}$ are represented. Moreover, the only two fragments not written in a Brahmī were found in this city (sH 645 and sht 646). The variety of this material calls for a deeper analysis, in order to add some more solid bricks to the reconstruction of this picture.

First of all, almost all xylographs are printed on paper with black ink. The only notable exception is SHT 646, printed on paper with red ink. The layout of the pothi xylographs contains South Asian, Tibetan and Chinese elements. Particularly interesting are the bigger fragments, such as the ones transmitted in SHT 612 and sнt 645 . Fragments of sixteen folios (157-173) of sHT 612 are extant, and one almost complete folio (173). This complete folio (figures 6.2 and 6.3) measures $10.8 \times 28$, and has five lines per folio on both sides. Like in many Central Asian manuscripts of Sanskrit texts, the ratio between the characters and the interlinear space is roughly $1: 2$, rendering the text very reader friendly. It has a single-lined writing frame surrounding the whole writing area, and a string hole space, $15.5 \mathrm{~cm}$ from the left side, interrupting lines 2-4, decorated with a lotus. The running title in Chinese characters is written on the left margin of the recto, while on the left side of the verso the running title is given in Sanskrit and Uighur. The running marginal titles are separated from the text by means of a line thinner than the frame lines. Although the overall aspect of the folios resembles that of a manuscript - even the string-hole space is echoed by means of the decorative lotus - the writing frame and the marginal titles seem to be peculiar features of printed pothis, and are lacking in the accordion

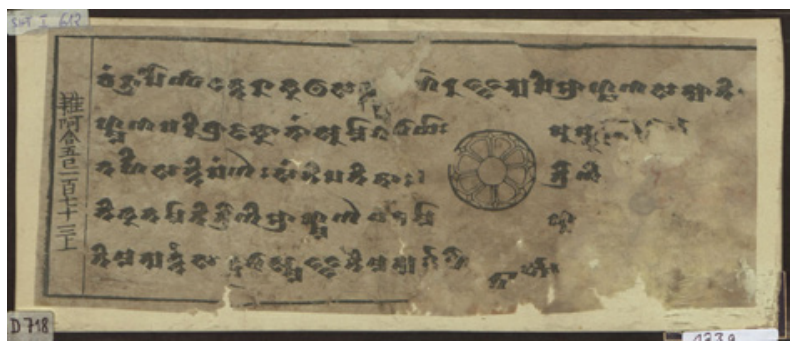

FIGURE 6.2 SHT 612, folio 173 recto (for a complete description, see Appendix A).

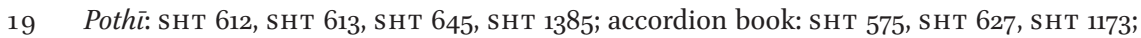
codex: SHT 614a, SHт 646.

20 Canonical: sнt 612, sнt 613; ritual/performative: sнт 575, sнт 614a, sнт 614b, sнt 627 , SHT 645, SHT 1385; magical and protective spells: SHT 646, SHT 1191. 


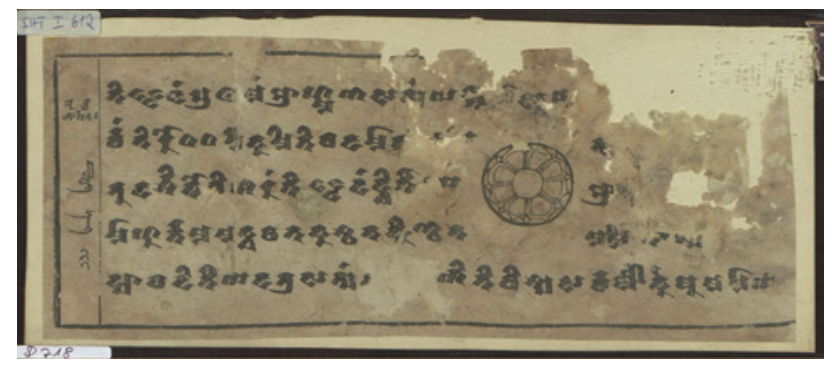

FIGURE 6.3 SHT 612, folio 173 verso ( for a complete description, see Appendix A).

books. ${ }^{21}$ Very similar considerations can be made for sHT 645 (figures 6.4 and 6.5), seventeen folios of a xylograph of the Śatasāhasrikā Prajñāpāramitā. ${ }^{22}$ The four complete folios measure $16 \times 37$, are printed on both sides and have 6 lines per folio. On the left margin of each recto and verso, an abbreviated running title (including chapter titles) in Pāla script is provided, while on the right margin of each recto and verso, part of the chapter number and foliation is provided in Chinese script.

Accordion books tend to have a simpler layout. The most complete example is SHT 575 (figure 6.6), which consists of a continuous sheet of paper divided into three folios by leaving a blank space corresponding to approximately four written lines, with single marginal frame lines. The absence of running marginal titles and foliation could be explained by the format and its usage. These books were Gebrauchsobjekte: the reader had one verso and recto before the eyes, and to read the following verso and recto he/she just needed a slight movement of the hand to turn two pages at time, the risk of turning to the

21 Compare this description with the description of Uighur pothis in Gabain (1964, 174), and above all in Gabain $(1967,24)$ : "Einige wenige Blätter haben eine Form, die den handschriftlichen Blättern im 'Hochformat' ähnlich ist [...] Sie haben eine Breite von etwa $59 \mathrm{~cm}$, eine Höhe von 24,5 cm; der Schriftspiegel ist etwa 18,5 cm hoch und von einem Doppelrand eingerahmt, das Papier ist dünn; es gibt kein Schnurloch mehr, aber an dessen einstiger Stelle ist noch immer ein Kreis gezeichnet; er ist ohne Zirkel gezogen, denn es gibt kein Einstechloch. Er unterbricht die 8.-10. Zeile oder die 6.-8. Zeile. Die Paginierung befindet sich links, zwischen der Randlinie und der 1. Textzeile: zuoberst ist sie in uigurischen Buchstaben und darunter auf Chinesisch gegeben."

22 One fragment assigned to SHT 645 is without foliation, but with the running title [pañ] $c \bar{a}$ vi sā in Brāhmī script, suggesting that the fragment belonged rather to a xylograph of the Pañcaviṃśatisāhasrikā Prajñāpāramitā. 


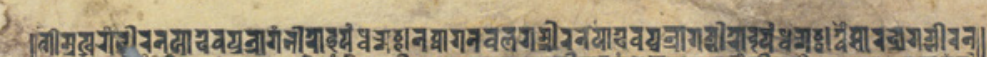

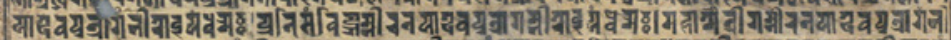

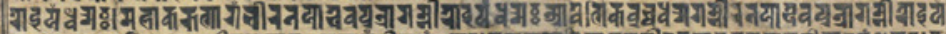

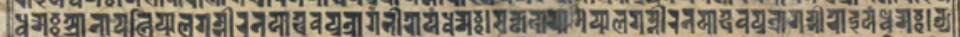

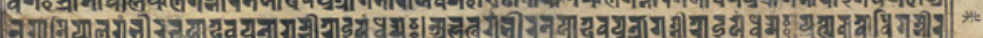

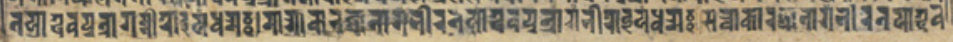

FIGURE 6.4 SHT 645, folio 30 recto (for a complete description, see Appendix A).

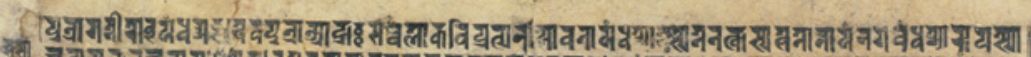

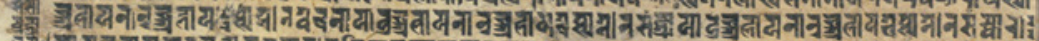

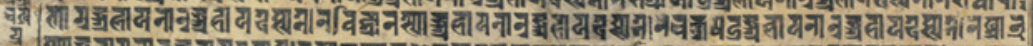

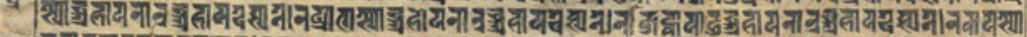

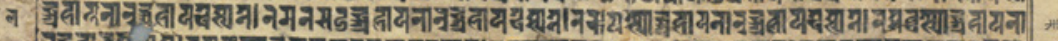

).

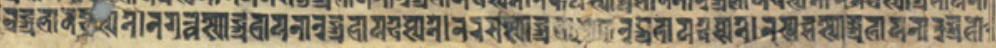

FIGURE 6.5 SHT 645, folio zo verso (for a complete description, see Appendix A).

wrong page was minimal. SHT 1190 consists of a single folio, and has double marginal frame lines (with a thicker external line).

SHT 646 (figures 6.7 and 6.8) is the only item whose state of conservation allows one to conclude with a degree of certainty that it belonged to a codex. Since it is printed on both sides, it is unlikely that it belonged to a butterfly book (although this possibility cannot be ruled out). It consists of two fragmentary folios, and is a unique item also in other respects: it is the only xylograph printed in red ink, and like sн $\mathrm{T} 645$ is written in an ornamental script derived from the Pāla script. The left and right margins of both folios are damaged, but most probably the writing 6area was completely delimited by a double frame, with a thicker external line.

Among the whole body of written material recovered in Central Asia, printed books were found only in sites on the northern route of the Silk Road (the Turfan oasis, Khara-khoto and Dunhuang), and only in six languages (Chinese, Uighur, Mongolian, Sanskrit, Tibetan and Tangut) (Gabain 1967). Even if the xylographs recovered in Qočo represent only a very small part of the findings if compared to the manuscripts, they show what appears to be a very diversified production, covering a wide range of languages and typologies of texts and book formats. The Sanskrit printed material examined presents features very 


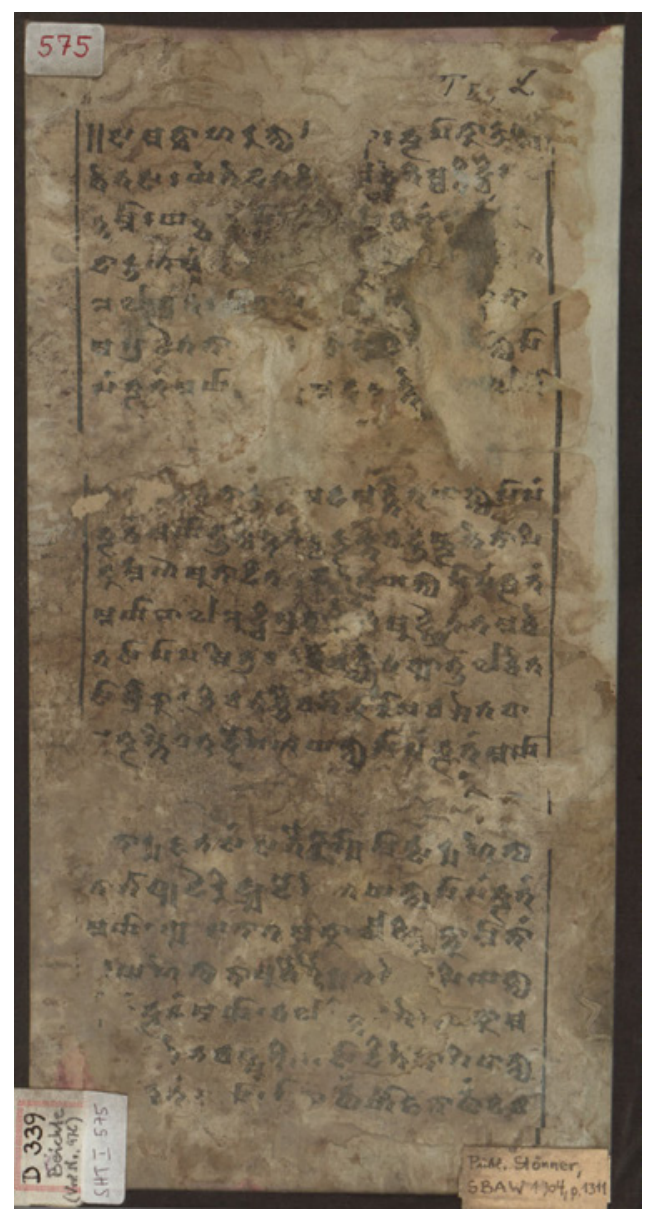

FIGURE 6.6

SHT 575, recto ( for a complete description, see Appendix A).

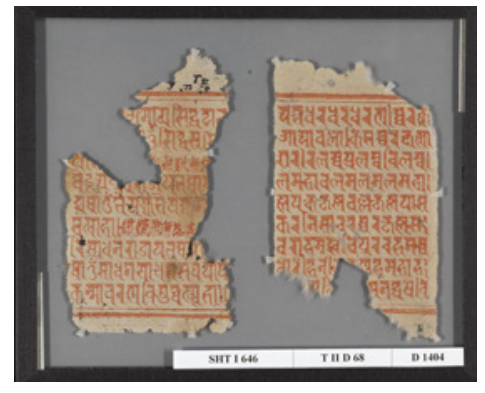

FIGURE 6.7 SHT 646, recto (for a complete description, see Appendix A).

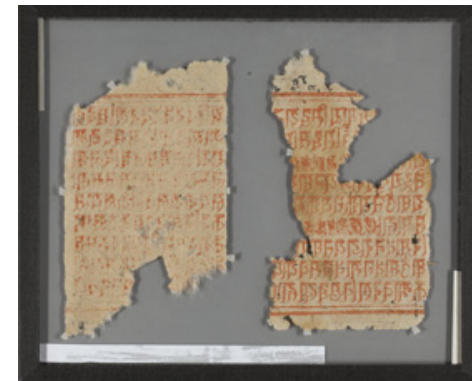

FIGURE 6.8 sHT 646, verso (for a complete description, see Appendix A). 
similar to the blockprints in other languages (above all the Uighur prints) ${ }^{23}$ In the light of these considerations, we might be tempted to reconstruct a picture in which Qočo was the seat of a printery that supplied also the neighboring cities and temples with Sanskrit texts. The local origin of the Turfan prints has already been questioned by P. Zieme $(2009 \mathrm{~b})$, and indeed a whole different picture emerges if we widen our perspective and take into consideration xylographs in other languages. Since the blockprints in Chinese, Tibetan and Sanskrit do not contain colophons mentioning the place of production, it is easy to assume that they were produced in the same place where they were found. On the other hand, a closer look at the colophons of Uighur prints in which the printing place is mentioned reveals that they were not printed in Qočo. After a perusal of Y. Kasai's Die uigurischen buddhistischen Kolophone, I was able to trace thirty-three colophons in Uighur extant blockprints, ${ }^{24}$ but only seven colophons contain a reference about the printing place. Five xylographs were printed in Dadu, the capital of the Yuan emperors (near present-day Beijing):25

(1) an Uighur version of the Chinese sūtra Fo shuo guan wu liang shou fo jing (no. 12), translated by Cinasiri (Skt. Jinaśrī) in the 14th century;

(2) the Sarvatathāgatoṣnịșasitātapatradhāraṇi) (no. 45), printed in 1298 in ten thousand exemplars (according to Kasai, the whole printing project probably lasted one year);

23 Cf. Gabain 1967; although slightly dated, this is a fundamental and very insightful contribution about Turfan printing culture.

24 The following list of Uighur blockprints is based on the examination of the 156 entries in Kasai 2008 (the first number is the one assigned by the author in her book, followed by the page number): 4 (p. 52), 8a-b (p. 6o), 10 (p. 63, 11 (p. 64), 12 (p. 65), 15 (p. 71), 40 (p. 112 ), 41 (p. 115), 42 (p. 118), 43 (p. 121), 44 (p. 122), 45 (p. 123), 48 (p. 129), 50 (p. 132), 68 (p. 155), 109 (p. 207), 110 (p. 208), 111 (p. 209), 128 (p. 235), 129 (p. 239), 130 (p. 243), 141 (p. 260), 142 (p. 260), 143 (p. 261), 144 (p. 261), 145 (p. 262), 146 (p. 264), 147 (p. 264), 148 (p. 265), 149 (p. 265), 150 (p. 266), 154 (p. 272), 155 (p. 273). Unfortunately, the indexes to the volume are of no help in this case too, and the only way to determine which blockprints contain a colophon is to read all entries. Like in the case of the eleven SHT volumes, one or more blockprints could eventually have escaped my attention. For this reason, I would like to appeal to the readers of this article and express one apparently minor request: if you are compiling a printed catalog, please consider the possibility of preparing also an electronic version, or at least think about the needs of the prospective readership, and provide accordingly a comprehensive index (or indexes).

For a discussion of these prints, see also Zieme 2009b. 
(3) the Mañjuśriñammasamgìti (no. 48) in the Uighur translation by Karuṇadāsa, completed in 1302 in the "White Stūpa Tempel (Chin. Bai ta si), in Dadu, and most probably printed in the same year and place;

(4) Avalokiteśvarasādhana (no. 110), in the Uighur translation by Punyasiri (Skt. Punyaśrī), printed in 1333 on behalf of the monks of the Pu qing si monastery;

(5) a multi-text accordion book (no. 130), containing six different texts (Chinese sütras, either in the original or in the Uighur version) printed on behalf of a certain Buyancog Bahsi, using the blockprints kept in the Hong fa si temple in the city of Zhongdu. The identification of this city with Dadu is controversial, and depending on it this xylograph was printed either in 1188 or (most probably) in 1308. The different hypotheses are discussed by Kasai, 243-44, who leans toward the identification with Dadu.

Another blockprint that probably was printed in Dadu contains the Uighur translation of the Avalokiteśvarasādhana by Punyasiri (Skt. Punyaśrī) (no. 111), printed in 1336 on behalf of a lay Buddhist, Böri Buka. A fragment from an accordion book of an unidentified text was printed in 1361 in Ganzhou (no. 154), and another fragment of an unidentified text was printed on behalf of the emperor in Zhongdu (no. 142). Unfortunately, for the latter no further details are available, and in the light of the consideration made about the multi-text accordion book (no.130), also in this case we are unsure about the identification of this city. Nonetheless, there is tenuous evidence that xylographs could have been printed in Qočo. An accordion book of the Suvarnaprabhāsottamasūtra (no. 40) was printed and distributed in the 14th century in one hundred exemplars on behalf of the Idiqqut Köncök for the benefit of his parents. Fragments of two other accordion books of unidentified texts (no. 144 and 149) printed on behalf of the Idiqqut Köncök have also come to light (according to the colophon, no. 149 was printed in five-hundred exemplars). Moreover, an accordion book of the Aparimitāyurjñānanāmamahāyānasūtra (no. 42) was printed and distributed in one hundred and ten exemplars, on behalf of Buyan Kaya Sal, the sister of the Idiqqut Köncök's wife. The location of this family is controversial, they might have been the Idiqqut of Qočo or of Yongchang (Kasai 2008, 112-13; Zieme 1992,

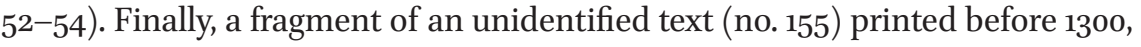
and probably commissioned by the empress Buluran, was found in Dunhuang.

Tempting as it might be, the hypothesis of a printing house active in Qočo seems improbable. The important role played by the Uighurs at the Mongolian court in the 13th and 14th century certainly accounts for the production of the Uighur prints. The role of the Mongols in the printing of Tibetan texts is also well known, as well as their involvement in the printing of Chinese texts. An 
excellent example of the skilfulness of the printers active in the Mongolian capital in the 14th century is provided by the quadrilingual prints of the Namaskāraikaviṃśatistotra to Tārā, containing the Sanskrit text in Pāla script, along with the Tibetan, Mongolian and Chinese translations (Zieme 1982, 1989). A similar type of print has been found also in the Turfan area, TibHT 107. These two fragments of a xylograph contain the Namaskāraikavimiśatistotra in three languages: the Sanskrit text in Pāla script, the Tibetan translation in dBu can, and only three characters in Uighur script and language. ${ }^{26}$ The texts are printed under the image of two different forms of this deity. Is it too far fetched to assume that also TibHT 107 was a quadrilingual xylograph? Moreover, if we assume that also the Sanskrit xylograph were printed in Dadu, the use of the Pāla script in SHT 645 and sн T 646 is easily explained with the Tibetan cultural influence at the Mongolian court (as explained above, the Pāla script in its derivative forms was employed in Tibet for ornamental purposes). Likewise, we can account for the multilingual marginal titles and foliation in SHT 612 and sHT 645, which most probably had the function of instructions for Chinese and Uighur printers (or librarians?). ${ }^{27}$ Another interesting witness of the broadness of this printing activity is SH T 646 , in the middle of which (lines 3 and 6) Tangut characters are to be found.

On the other hand, this explanation raises daunting questions: why were the Sanskrit xylographs found in Qočo? Who commissioned them? What was their purpose? The great variety of languages in these xylographs almost automatically leads to questions about multilingualism in Turfan. It is an accepted view that there must have been quite a few Uighur-Chinese bilingual individuals (Gabain 1967, 28-29), but the question remains of the status of the Sanskrit and Tibetan texts. Sanskrit can be considered the "church language" of Central Asian Buddhism, and given the ritual value of the hymns, we might speculate that the Sanskrit and/or the Tibetan versions of TibHT 107 were recited even by persons who didn't understand the languages (after all, they were provided with a translation on the same page).

Even if this hypothesis explains the occurrence of other ritual or magical Sanskrit texts (like the dhäraniss), the purpose of canonical texts such as the Samyuktāgama remains unclear. Were they meant to be read? If yes, by whom? How well-known was Sanskrit during the Uighur domination in Turfan? A

26 For the identification of the language, see Zieme 1989. The fragments preserve parts of the first and third pāda of stanza 5 in TibHT 107b (first line, 5 a: namas tuttārahūṃkā $[r a]$; second line, ${ }_{5}$ : $[s a]$ ptalokakramā $[k$. $\left.]\right)$, while TibHT 107a preserves parts of the second and fourth pāda of stanza 6 (first line, 6ab: [ma] | marudviśveśvarārcite |; second line, 6d: yakșapuraskrte).

On the function of the Chinese foliation in Uighur prints, see Gabain 1967, 27-28. 
comparison of the Sanskrit printed texts recovered with the extant Uighur Buddhist literature might provide an answer. Given the fragmentary character of the findings, obviously what we are looking for is not an exact correspondence, but rather a correspondence in terms of the typology of the texts (for instance, parts of the Vinaya, regardless of which exact parts). Almost all identified Sanskrit texts represented in the xylographs have Uighur counterparts:

1. Āgamas: Samyuktāgama (Appendix A nos. 3 and 4; cf. Elverskog 1997, 20-22, no. 3); Cittānupaśyanā-Smrtyupasthāna and DharmānupaśyanāSmrtyupasthāna (Appendix A nos. 5-6; Elverskog 1997, 18-20, no. 2 Madhyamāgama);

2. Vinaya texts (Appendix A no. 16, Samghabhedavastu; CF. Elverskog 1997, 31-31-22, nos. 11-12, Vinayavibhañga of the Mūlasarvāstivādins and of the Sarvāstivādins);

3. Suvarnaprabhāsottamasūtra (Appendix A no. 1, Deśanā corresponding to Suvarnaaprabhāsottamasūtra III.17-27; cf. Elverskog 1997, 65-71, no. 37; 135-38, no. 79$) ;{ }^{28}$

4. Catușparișatsūtra (Appendix A no. 1; cf. Elverskog 1997, 26-27, no. 7, Disastvustik);

5. Stotras (Appendix A no. 7; cf. Elverskog 1997, 126-29, no. 75 B);

6. Dhāraṇis: Sitātapatrahṛdayamantra and Sarvatathāgatoṣnūṣasitātapatradhäraṇī (Appendix A no. 13 and 17; cf. Elverskog 1997, 108-110, no. 62; Sarvatathāgatoṣnịșavijjayanāmadhāraṇī (Appendix B no. 14; cf. T III M 209).

The only Sanskrit text without any Uighur correspondence is the Śatasāhasrikā Prajñāāäramitā (sнт 645, to which one may add sн т 646, an unidentified Dhāran̄i $)$. Is this a fortuitous case, or did the Prajñāpāramitā enjoy a different status than other Sanskrit texts? As we have seen, sнt 645 is a peculiar print (pothī in Pāla characters), probably it had a cultic value and was meant to be worshipped rather than read. A similar remark can be made also for the dhäranīs and the stotras: the former had magical protective value per se, while the latter were perhaps recited in the original Sanskrit. If we turn to the rest of texts, the Āgamas, the Vinaya texts and the Catuṣparișatsütra, we have to come up with a different explanation. According to Elverskog, the Uighur versions

28 On the centrality of this Deśanā for the development of the Suvarnaprabhāsottamasūtra, cf. Nobel 1937, and Elverskog 1997, 65: "The text probably was built up around the confession of sins found in chapter 3 of the Sanskrit version, and over time it was continually expanded with the addition of jätaka stories, an exposition of śünyatā (emptiness), political ideas of kingship, and certain Tantric concepts." Cf. also the metrical Deśanā in sHT 1105, Appendix A no. 10. 
of the latter two were translated from a Sanskrit original $(1997,10)$. Is this the explanation for the presence of Sanskrit xylographs of such texts, even after the Indian missionary activity in Central Asia had ceased? A confirmation of this hypothesis might be found in the bilingual Sanskrit-Uighur manuscripts recovered in the Turfan area. In fact, these fragments include parts of the Vinayavibhañga of the Mūlasarvāstivādins, as well as of the Samyuktāgama and the Madhyamāgama (Gabain 1954, Hartmann and Maue 1996, and Maue 1996). Maybe the Sanskrit prints of these texts were based on the manuscripts used for the Uighur translations, and were still used as reference works in a monastic environment (or to learn Sanskrit?).

\section{Sanskrit Lithographs}

We now turn to the world of lithography, the first printing technology that made a real impact in South Asia and had more immediate and far-reaching effects than typography. Invented by Alois Senefelder in Munich in 1798, lithography is based on a relatively simple process:

The key to the process is the basic principle that grease and water do not mix. If marks are made on a flat, porous stone surface with a waxy crayon or other greasy substance it will stick to the stone and be partially absorbed. The whole surface can then be moistened and the water is attracted to the stone but repelled by the grease. If the stone is then inked up with greasy printing ink, the ink will adhere to the greasy marks but be repelled by the water. The ink can then be transferred to a sheet of paper through the application of pressure. Unlike relief printing where the printing surface is raised, or intaglio where the ink is contained in incised grooves in a metal plate, in lithography the printing surface is flat. (Banham 2007, 284)

The introduction of lithography in South Asia has already been described in detail by G. Shaw, therefore I mention here only the relevant details. Lithography was introduced in South Asia in the 1820s, and the two main centers of production were Mumbai and Calcutta (Shaw 1993, 91; Shaw 1998, 91). Soon it became clear that the technique had to be adapted to the Indian climate, and many technical shortcomings had to be dealt with. Particularly important was the preparation of the stones and the inks (for the latter, special recipes were developed, see Shaw 1993, 91).

Lithographic printing was widely employed for the production of books in Hindi and Urdu, and accordingly the scholarly literature on this topic 
is vast. ${ }^{29}$ On the contrary, virtually no specific study has been devoted to Sanskrit lithographs. Nevertheless, even a cursory examination of selected catalogues confirms the great popularity enjoyed by this technique in South Asia for printing Sanskrit books as well: 807 lithographs are listed alone in the Nepal German Manuscripts Cataloguing Project (NGMCP) database. Unlike in the case of xylographs, where the (unfortunately) limited amount of material at our disposal allowed a comprehensive study, it is not possible to provide a complete analysis of such a vast amount of material. A bibliographical study of Sanskrit lithographs is still a desideratum, and as long as no reliable census is available, we are left in the blind as to what kind of Sanskrit works have been published by means of this printing technique. Therefore, a reliable study on the impact and circulation of Sanskrit lithographs has to be postponed. Nevertheless, a close examination of selected material might reveal other aspects of lithographic print culture, which might have had an impact on the attitude of readers towards the printed book. I focus here on one example of a Sanskrit lithograph, the Śüdrakamalākara by Kamalākarabhațta, a Sanskrit manual about the conduct of life and social behavior for śüdras composed in the 17th century (cf. Kāne 1930, 432-37). This lithograph was published in Mumbai in 1861 and is currently kept in the Cambridge University Library (figures 6.9-6.13). Although printed in the pothi format, it is now bound as a volume in the codex format. The manuscript of the Śüdrakamalākara examined here (figures 6.14-6.17) is kept in the Anandashram Samstha in Pune. According to the colophon, it was written in 1817 in the Kṛ̣nạātīramsālī (?)

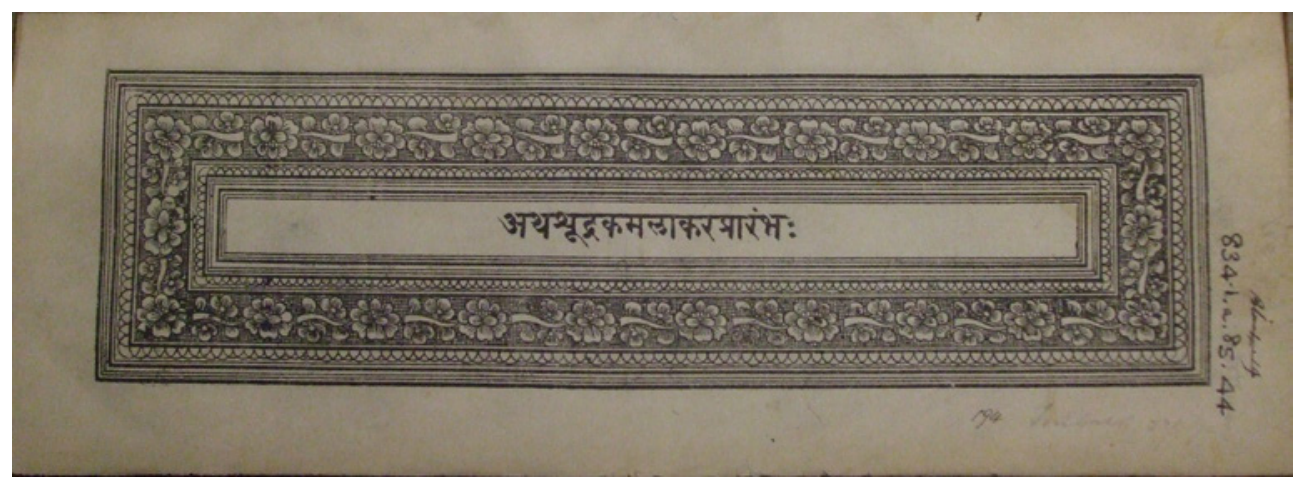

FIGURE 6.9 Lithograph of the Sūdrakamalākara, folio 1 recto, title page. Black and white illustration imitating wooden covers of manuscripts ( for a complete description, see Appendix B).

29 See for instance the works listed in Stark 2007. 


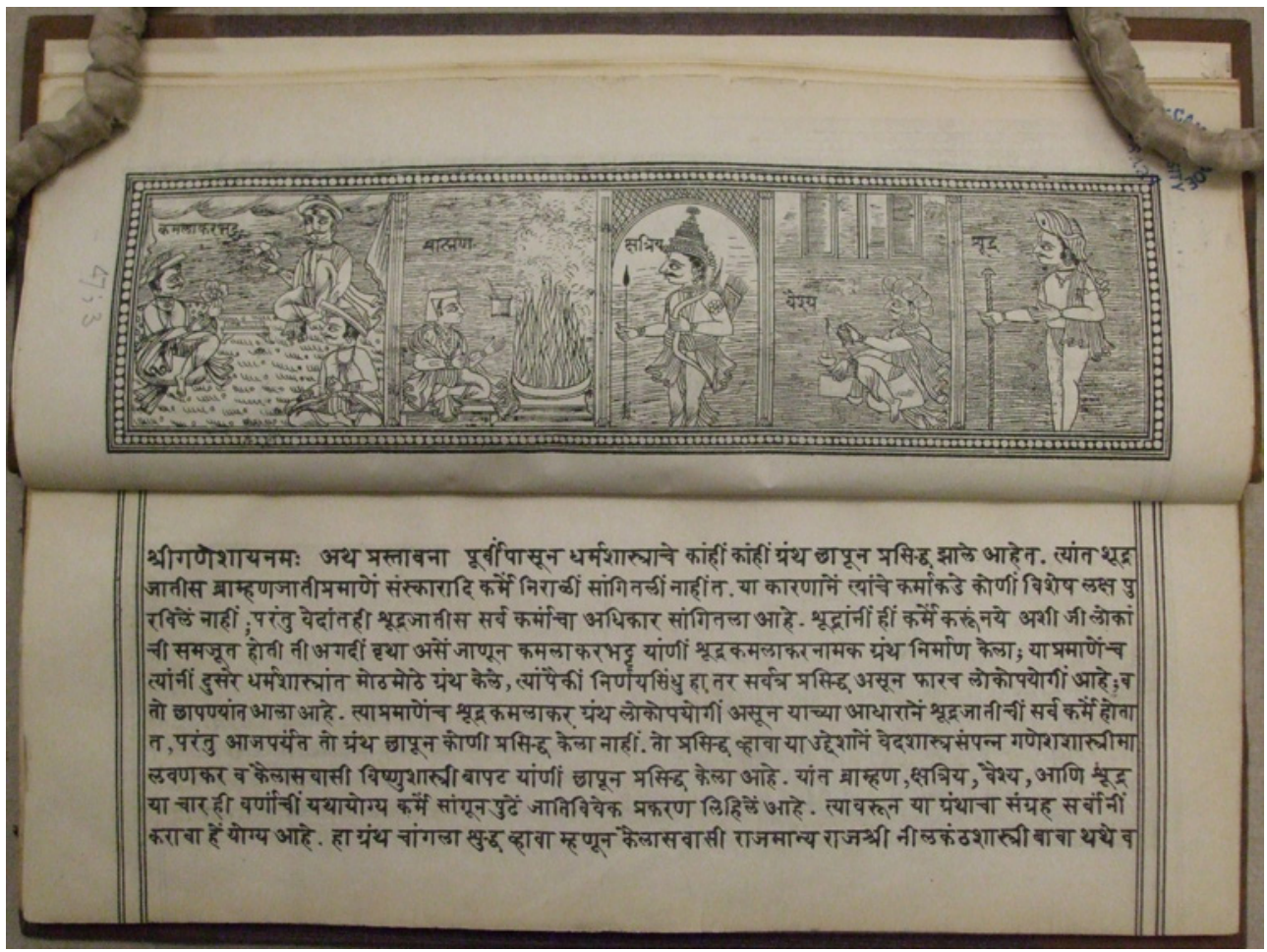

FIGU RE 6.10 Lithograph of the Sūdrakamalākara, folio 1 verso. Black and white illustration divided into four panels (from left to right: the author of the treatise; figures representing the four varṇas in this order: brāhmaṇa, kṣatriya, vaiśya, and śūdra), and folio 2 recto (for a complete description, see Appendix B).

village by a certain Bāka for his own use as well as for others. Most probably the scribe was not a professional, and the overall impression conveyed by the script and the carelessly planned layout confirms this conclusion. A detailed description of both manuscript and lithograph is provided in Appendix B. A comparison of the layout features of the lithograph with that of the manuscript shows that basically there are no differences between the two: they are both pothis, the writing space is delimited only by double marginal frame lines, and for the segmentation of the text the same set of symbols and strategies are used. Moreover, paratextual elements such as the running marginal title and the foliation are in identical positions in both the manuscript and the lithograph. Finally, pieces of information that in Western printed books are usually found in the title page, such as place and year of printing, are provided in a colophon after the main text. In the lithograph and the manuscript of the Śüdrakamalākara, the structural elements of the two colophons are identical, as shown in the following table: 
TABLE 6.1 Structural analysis of the colophons in the Śüdrakamaläkara manuscript and lithograph.

\section{Element}

Name of era

Year

Name of year

Month / fortnight / day

Place of production

Formula of completion

Name of scribe

Scribal note

\section{Manuscript}

śake

1739

î́varanāmasaṃvatsare

caitravadyapratipadāṃ,

saumyavāsare

kṛṣnātīraṃsālīgrāmamadhye

idaṃ pustakaṃ [...] nirmitam samāptam

bhațtopanārakagoviṃdabhaț̣ātma- yatnataś ca gạ̣eśena jabākena likhitam

svārthaṃ parārthaṃ ca [...]

evaṃ vādati pustakaṃ || śrīrāma ||

\section{Lithograph}

\section{śake}

1783 trināgasapteṃdumite

durmatināmasamvatsare

mārgaśīrṣamāsi,

kṛ̣ṇapakṣe, ravivāsare

muṃbākhyapațțaṇe

idaṃ pustakaṃ samāptam aṃkito 'yam śilākṣaraih

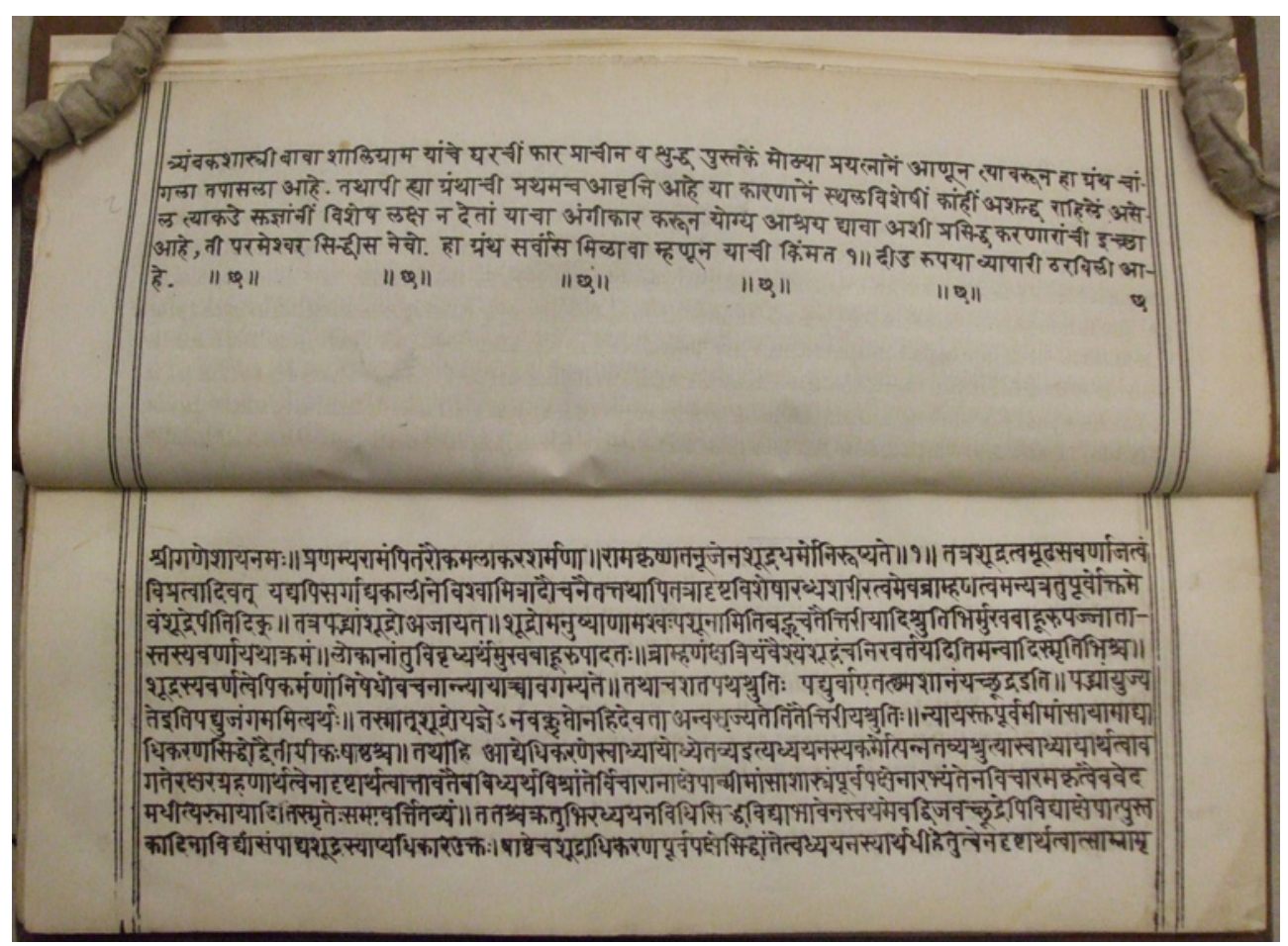

FIGURE 6.11 Lithograph of the Śñdrakamalākara, folio 2 verso and 3 recto (for a complete description, see Appendix B). 


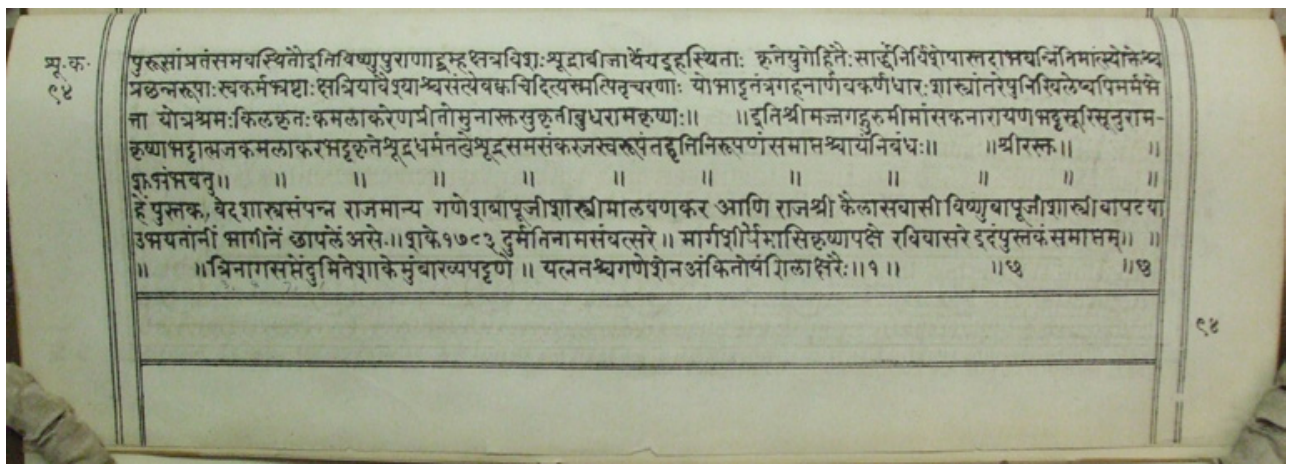

FIGURE 6.12 Lithograph of the Sūdrakamalākara, folio 94 verso, colophon ( for a complete description, see Appendix B).

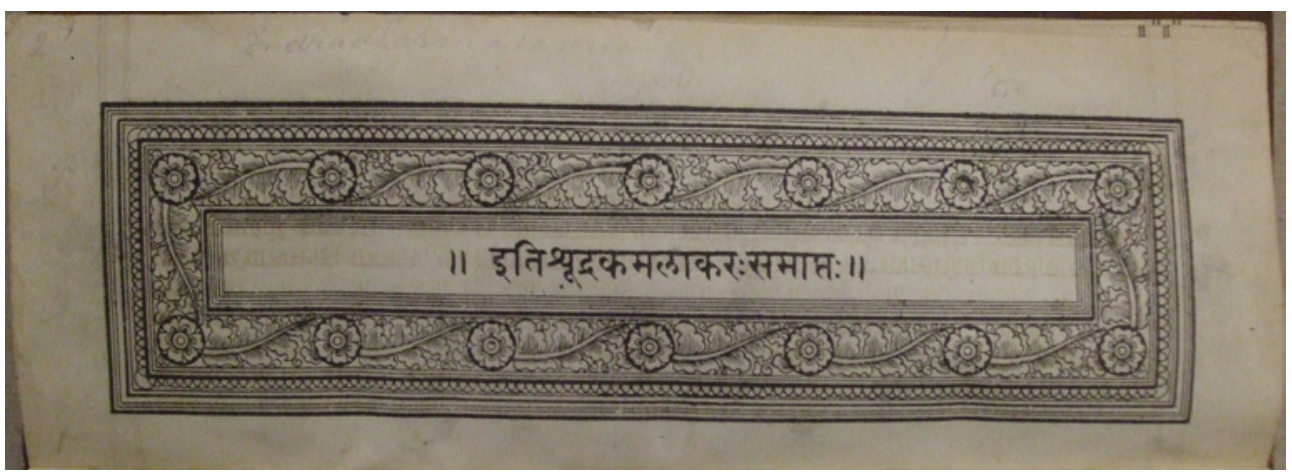

FIGURE 6.13 Lithograph of the Sūdrakamalākara, folio 95 verso. Black and white illustration imitating wooden covers with carved floral decorations (for a complete description, see Appendix B).

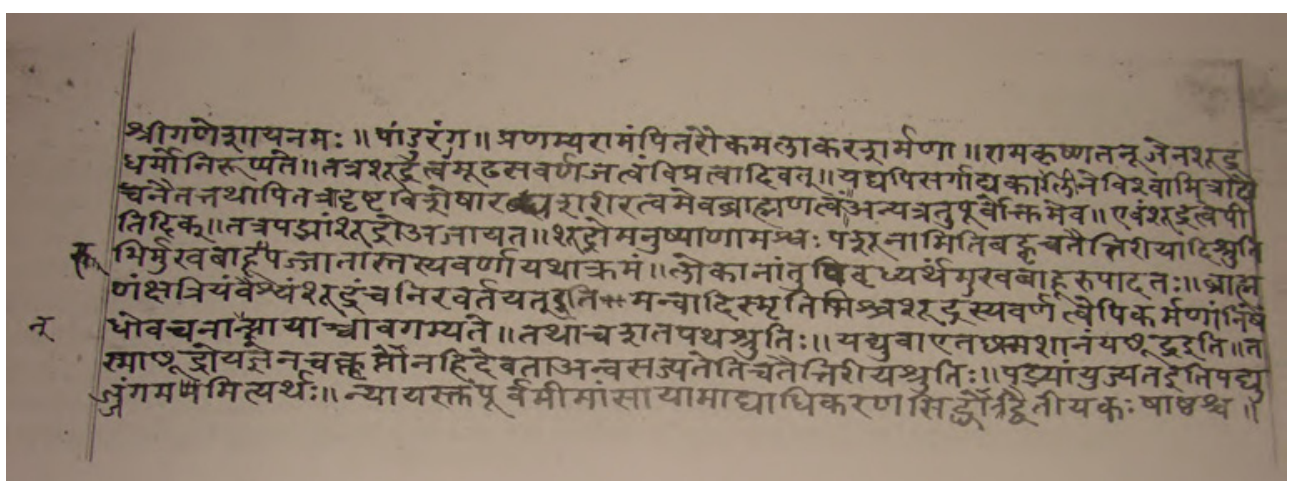

FIGURE 6.14

Manuscript of the Sundrakamalākara, folio 1 recto (for a complete description, see Appendix B). 


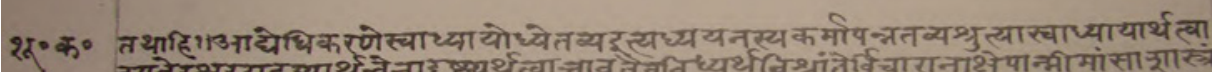

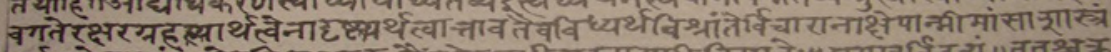

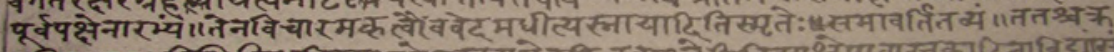

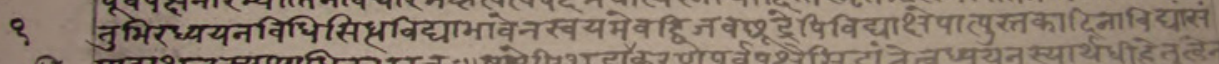

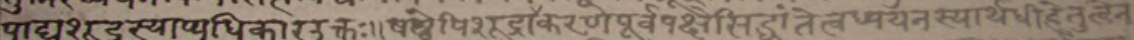

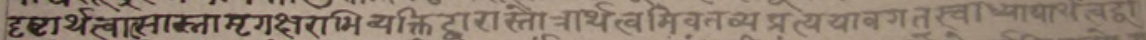

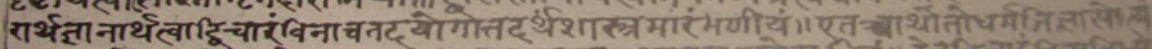

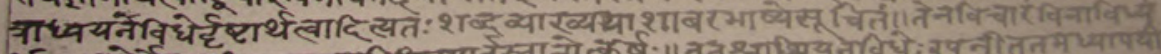

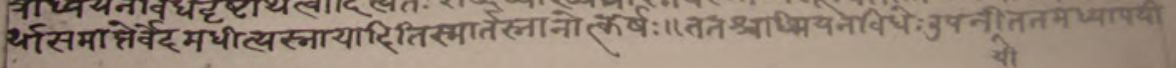

FIGURE 6.15 Manuscript of the Sundrakamalākara, folio 1 verso (for a complete description, see Appendix B).

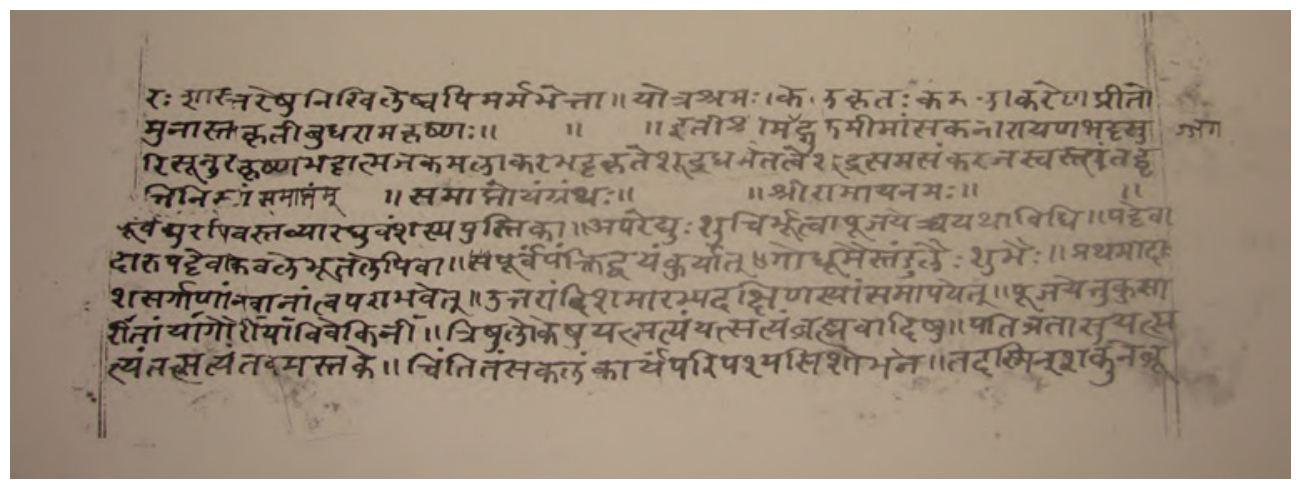

FIGURE 6.16

Manuscript of the Sūdrakamalākara, folio 124 recto, colophon (for a complete description, see Appendix B).

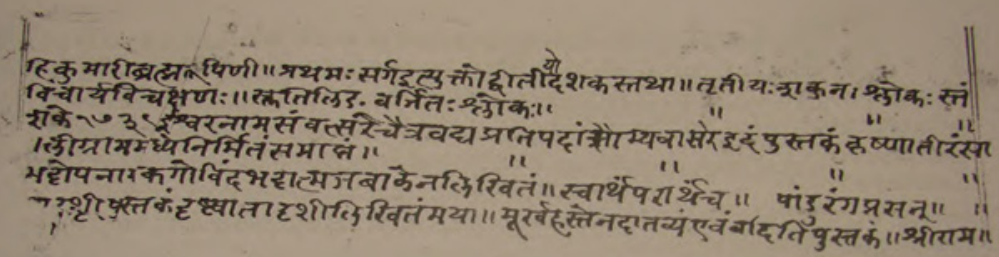

FIGURE 6.17

Manuscript of the Sūdrakamalākara, folio 124 verso, colophon (for a complete description, see Appendix B). 
The only differences lie in the terminology employed to indicate the name of the scribe, and the absence of the scribal note in the lithograph. If it is clear that the manuscript was written (Skt. likhitam) by a certain Bāka, son of Govinda, the terminology for the preparation of the lithograph is ambiguous. We know that a certain Ganeśa printed the text (Skt. ankito, scil. granthah) with effort (yatnatah) by means of lithographic process (Skt. śiläkșaraih, lit. "stone characters"). For the preparation of a lithograph, a manuscript had to be written, which was subsequently pressed on the stone. Was Ganeśa the scribe and the printer as well? Or does the word ankita only mean that he prepared the manuscript? Moreover, if we take into consideration that at least three different hands can be distinguished (as described below in the Appendix B), the plot thickens: was Ganeśa only the last scribe, and did he not credit the others? Or is the change of hand to be ascribed to different writing tools used by him in the preparation of the master copy?

The scribal note in the manuscript includes three elements: the indication of the purpose of the manuscript ("for my own sake as well as for the sake of others"), followed by very common statements usually added at the end of manuscripts in metrical form ("I have written this book as I have seen it. 'Do not give [me] in the hand of fools!' says the book"); an invocation to Rāma closes the whole manuscript. It should be stressed that although quite common, scribal stanzas are not always present in manuscripts (and very often they are written in poor Sanskrit, like in this case: the first two pādas should read either yādrśam pustakaṃ dṛștvā tādrśam likhitam mayā or yādṛsím pustikām dṛștvā tādṛ́si likhitā mayāa).

The codicological features as well as the paratextual elements of the lithographed book reveal the clear intention of imitating manuscripts. This sort of imitation is pushed to such an extent that the recto of the first folio and the verso of the last folio are imitations of wooden covers of manuscripts (see the section about layout in the description provided in Appendix B).

\section{4 \\ Sanskrit Incunabula}

In order to get an idea about the Sanskrit works printed in South Asia in the pre-colonial period, the first step is to turn to Graham Shaw's (1987) The South Asia and Burma Retrospective Bibliography (SABREB). Stage 1, 1556-180o. This is what I did, but what I found was rather disappointing. According to Shaw, prior to 1800 only a single Sanskrit work had been printed in South Asia: the Rtusamhära, or as it runs in the title of the printed volume, "The seasons: a descriptive poem, by Cálidás, in the original Sanscrit." This book was printed in 
Calcutta at the Honorable Company's Press in 1792, and the "entire text is not printed in Devanāgarī but in Bengali characters" (Shaw 1981, 149). The editor was Sir William Jones, and it is important bibliographically as the first Sanskrit work ever printed with movable type in India. Calcutta confirms its role as a printing hub in South Asia also as far as printing with movable type is concerned, and the first Sanskrit works in Devanāgarī characters were printed in this city. Between 1801 and 1832, the Serampore Press of the Danish mission produced an output of "more than two hundred and twelve thousand volumes in forty different languages" (Grierson 1903, 241). The pivotal role of the Serampore Press has to be acknowledged also in that it developed and cast types for a wide range of South Asian scripts (ibidem). As is to be expected, the list of Sanskrit books printed at this press includes translations of the Old and New Testament. However, more interesting is the range of works printed in order to fulfil the needs of books in Sanskrit and other languages for the education of civil servants in the College of Fort William: William Carey's A Grammar of the Sungskrit Language (1804, 1806 and 1808), the Rāmāyāna (1806), the Mugdhabodha by Vopadeva ${ }^{30}$ (in Bengali characters, 1807), the Nāmalingānuśāsana by Amara (with an English interpretation and annotation by E. T. Colebrooke, 1808 and 1825), the Sänkhyapravacanabhāssya by Vijñānabhikṣu (in Devanāgarī characters, 2nd edition 1821) (Grierson 1903, 254). Moreover, Henry Thomas Colebrooke commissioned Carey to print a reader for the students of Fort William, containing "the Hitopadeśa fables, Appaya Dīkṣita's abridgment of Daṇ̣in's Daśakumāracarita story and Bharț̣hari's three śatakas (centuries) of poetical aphorisms" (Rocher and Rocher 2012, 73).

The Serampore press was not able to print enough books to fulfill the needs of Fort William College, and in 1807 a printing press entirely run by Indian personnel was established in the College, thanks to Colebrooke's support. In 1809 the press became independent under the ownership of Paṇ dit Bāburām. ${ }^{31}$ After the takeover by Bāburām, the press had a short life span, and "owed its survival until then to Fort William's need to adapt Sanskrit classics for classroom use" (Kopf 1969, 118). The very first books published by this press were Sanskrit works that were interesting to Colebrooke, mostly kośas. Among these books, particularly interesting is a volume including the Amarakośa, the

30 In this early period of Sanskrit studies, this grammatical treatise was deemed to be superior to Pāṇini's Aștāanhyāȳ̄ for didactical purposes (Rocher and Rocher 2012, 68-70).

31 Before 180o, the first printing press "used by Indians for Indians (without any direct European stimulus or involvement) was when two Parsee compositors working at the Courier Press in Bombay produced an edition of their Zoroastrian holy book, the Khordeh Avesta, in 1798" (Shaw 2007, 131). 
Trikāndaśeșa, the Harāvalī, and the Nānārthakośa by Medinī, together with an index by Paṇịit Vidyākara Miśra (Rocher and Rocher 2012, 74). The description provided by R. and L. Rocher's enables us to have a very precise idea of its nature: ${ }^{32}$

Setting a pattern of Sanskrit Press publications, it was printed in the traditional format of Indian manuscripts, oblong and without title pages, but with extensive colophons. Introductory verses announced that the book appeared 'at Mr. Colebrooke's behest' (Kolabrūka-sāhab-äjñayā). (Rocher and Rocher 2012, 74)

Like in the case of lithographs, for the sake of clarity and due to the editorial constraints, I have chosen to deal only with two early printed editions of one single work, Bhāravi's Kirätārjunīya. The first edition of this work (figures 6.18-6.20) was printed in 1814 at Fort William, when the press was under the direction of Babūrām. A closer look at some features of this Sanskrit incunabulum confirms that the style of the books printed by Bāburām is a simple adaptation of a manuscript with few minor differences. Even though the imprint/ title page is a feature that in the form seen here is absent in manuscripts, it retains elements of manuscript colophons. The number of verses (śloka) of the main text is indicated, as if it were a manuscript and the scribe would have to be paid (atra kārye mūlaślokasaṃkhyā \|l ekapañcāśadadhikasahasram 1052). The presence of introductory verses about the occasion of preparation of the edition resembles the scribal verses found in manuscripts. ${ }^{33}$ Finally, the publication date is given in four different calendars. Other features of manuscripts crept into this printed book, such as the use of foliation instead of pagination, and the nature and appearance of paratexts (running marginal abbreviated title, number of the sarga). Moreover, the overall layout of the complex main text-commentary is basically the same as in a manuscript in the tripattha format. The persistence of elements of manuscripts in incunabula is not peculiar to South Asian print culture, yet the choice of the Indian editors and printers

32 Although this description is rather fitting, the copy of this book I consulted (Cambridge University Library 834: 4.c.80.1) is not in the "oblong," i.e. pothi format of Indian manuscripts, but in the Western book format. Otherwise, the 1814 edition of Bhāravi's Kirātārjunīya examined by me has the same type of layout.

33 "Gildemeister (Bibliotheca Sanskrita, 1847,\# 331, p. 63) was puzzled by a king Mallāța mentioned in the mangala verses of Bābūrāma's edition of the Kirātārjunīya (Calcutta 1814), śrimallātanrpājñaya . In fact, the book was published at the instance of the lāta-nrpa, i.e., the governor-general" (Rocher 2009, 512). 


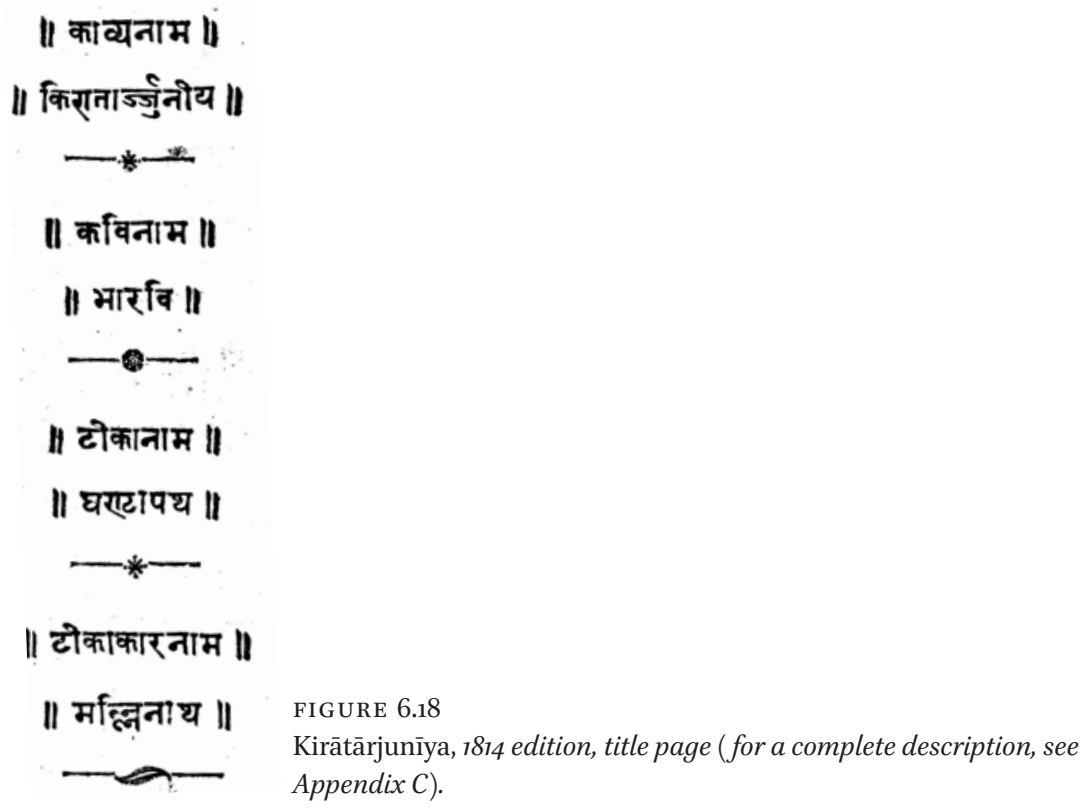

in the beginning of the 19th century was surely more deliberate than the one of their European counterparts in the 15th and 16th century. Even though they could rely on different models and draw inspiration from Western books set up with a different layout, they decided not to depart from the indigenous manuscript tradition.

On the other hand, the 1847 edition of the same work (figures 6.22-6.23) already shows features borrowed from Western printed books: the layout of the complex main text + commentary is completely different, the paratexts (running marginal abbreviated title and number of the sarga) have moved to the header, and instead of a foliation, a pagination is employed. However, the main difference between the two editions is in the degree of readability and the means employed to achieve it. In the 1814 edition (figures 6.18-6.21), the first stanza is printed in the middle of folio $1 \mathrm{v}$, slightly indented on the left and right, and separated from the preceding and following nine lines of commentary only by means of a double interlinear space. Moreover, it is preceded by the rubric (Skt. namaskāra) śríganeśāya namaḥ, like in manuscripts, and is printed on two lines, even though the meter has four lines (Skt. pāda). More importantly, both the text of the müla as well as that of the commentary are completely printed in scriptio continua. In other words, little thought has been paid to enhance the readability of this printed book against its manuscript counterparts. 


\section{|| अ्र ॠक्षाव्ये सर्गसंख्या || \\ स्मष्टादश १ุ॥ \\ *a* \\ \|) स्रनकाव्ये मूल स्लोंक संख्या ॥

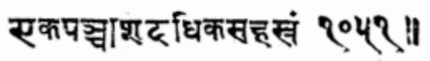 \\ 20}

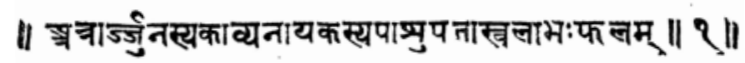

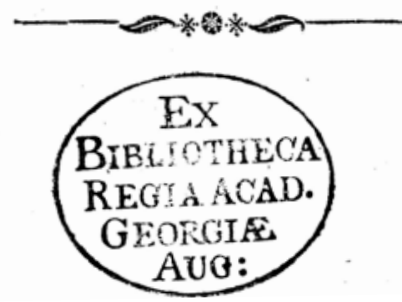

FIGURE 6.19 Kirātārjunīya, 1814 edition, page 1 (imprint; for a complete description, see Appendix $C$ ).

A very different approach has been adopted for the 1847 edition, in which the text is far more reader friendly. First of all, the layout solution for the main text and the commentary is a clear improvement. Albeit not always immediately under the stanza, the commentary to each stanza begins on the same page where the stanza is printed, and continues up to the next stanza in the main text, helping the reader considerably to navigate between the two. Other important improvements are that the stanzas are printed on four lines, representing their structure in four $p \bar{a} d a s$, and that the text is not printed in scriptio continua, the words are divided (even if not always, in the 


\section{|| शाकेव डग्निसच्नेन्दु सम्मिते दन्मरेशुमे ॥ \\ \| शाके श९३६ ॥ \\ || घन्द्रांट्रवनुमूमानेविकारिव्यवन्सरे ॥ \\ ॥ संवत् श्र०१" \\ "| मूयुग्मटृाष्ट्धर खींसंमिते यवनाष्टके ॥ \\ ॥ सन श२? साल ॥}

\section{1 ग्रायाढ स्य सिने प क्षेतृतीया से। म वा सरे ॥}

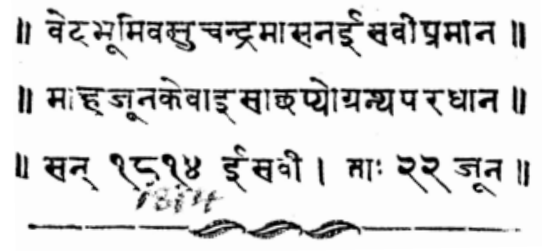

FIGURE 6.20

Kirātārjunīya, 1814 edition, page 2 (imprint; for a complete description, see Appendix C).

great majority of cases). For instance, in the 1814 edition the first stanza is printed as:

śriyaḥkurūṇāmadhipasyapālanīmprajāsuvṛttimyamayuñktaveditum、| savarṇilingīviditaḥsamāyayauyudhișțhiraṃdvaitavanevanecaraḥ || 1 ||

In the 1847 edition, however, it is printed as follows:

śriyaḥ kurūṇāmadhipasya pālanīm

prajāsu vṛttim yamayunikta veditum ||

sa varṇilingī viditaḥ samāyayau

yudhișțhiram dvaitavane vanecarah || 1 ||

The tendency towards printing more easily readable and better accessible texts did not cease, and later editions gradually introduced other means to facilitate 


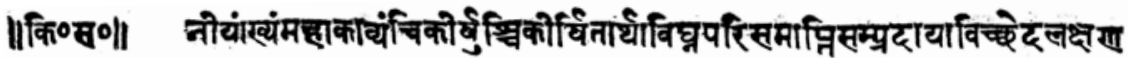

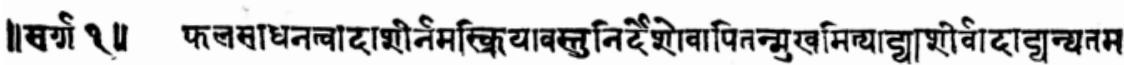

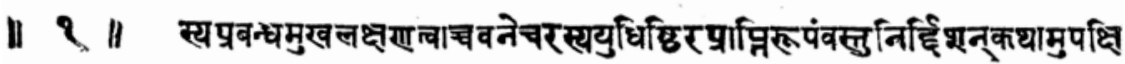

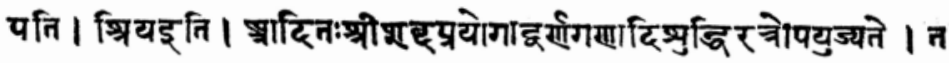

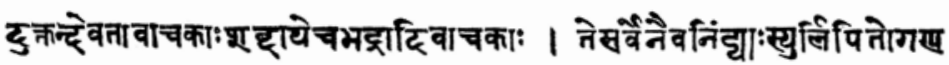

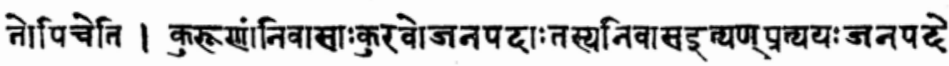

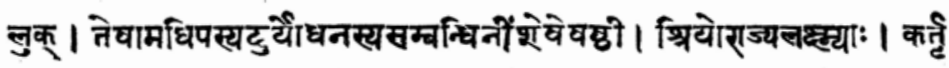

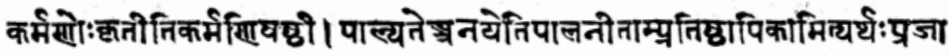

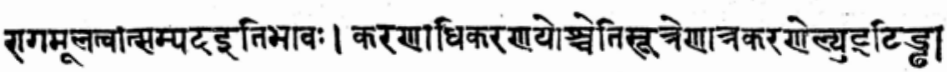

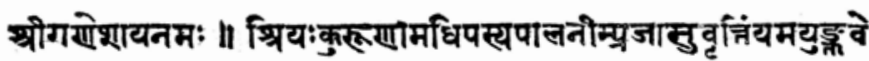

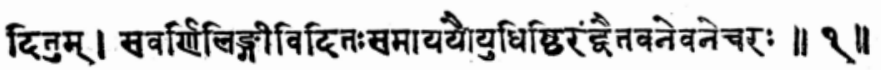

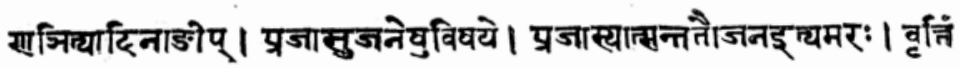

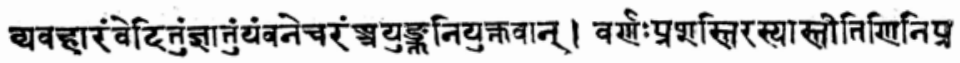

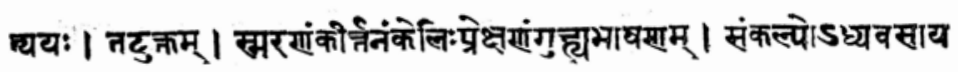

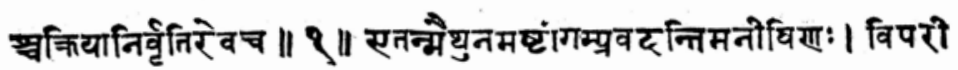

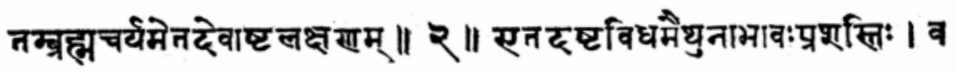

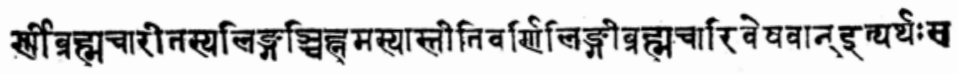

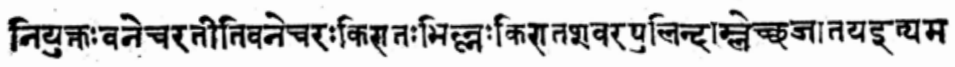

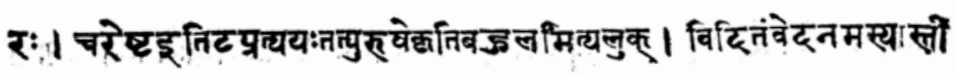

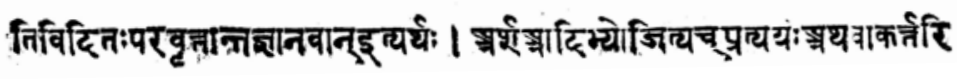
Kirātārjunīya, 1814 edition, folio 1 verso ( for a complete description, see Appendix C).

reading, such as types in different bodies to distinguish the main text from the commentaries (the former were usually printed with bigger bodies), or by printing in a bold face the first word of the main text when quoted as a lemma in the commentary (Skt. pratīka). 


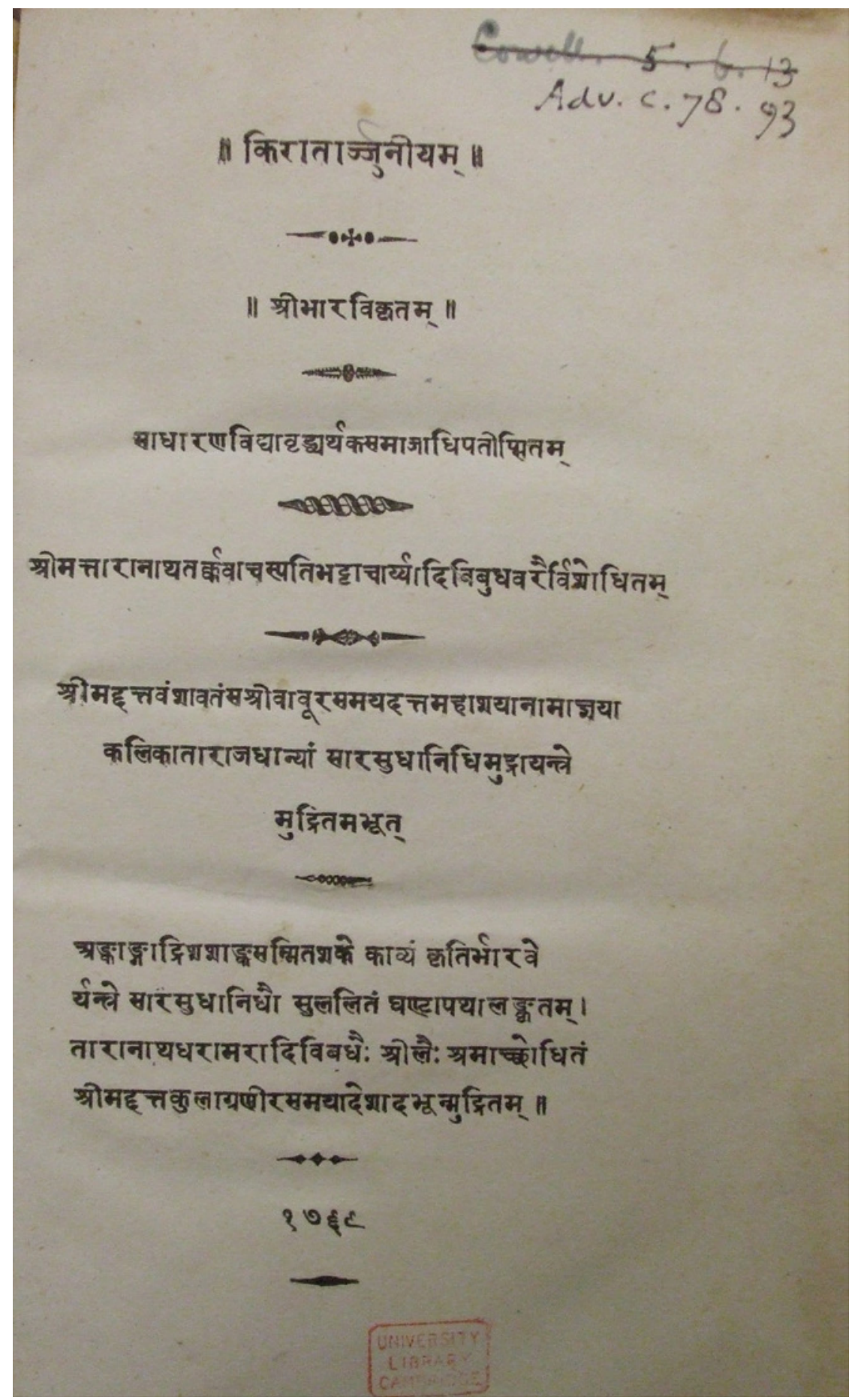

FIGURE 6.22 Kirātārjunīya, 1847 edition, imprint (for a complete description, see Appendix C). 
॥ श्रोगसेशाय नमः ॥

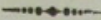

श्र द्वाज्नीक्षनदाम्पत्यमपि गा ढानुरागि यत् ।

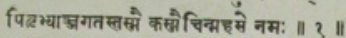

चाल्बे जगदालम्बं हेरम्बचर एामुजम् ।

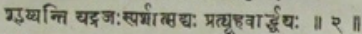

तड़्यिमययन्बाम सारस्ततमुपास है।

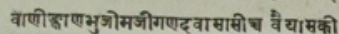

मन्तस्तन्त्नसंस्त पब्नगगबीगुम्छेषु चाजागरीत् ।

लोकेड मूघटुपज मेव विदुषां सेतनन्यजन्य यशः ॥ 8 ॥|

मध्भिनाथकवि: सोडयं मन्दात्मान्नुजिघंच्चा।

नत्किराता र्ज्नुनीयाख्यं काख्यं ब्याख्यातुमिच्छात ॥

नारिकेसफल्कर्मस्मितं बचेभारवे: सपदि तदिभज्यते।

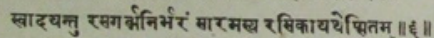

मानानिबन्धबिषमे कपदे निता न्तं

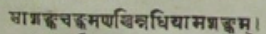

कर्तु म्भवेश्य मिश्ह भार विकाव्य बन्षे

घए्ठापथं कमपि नूरनममातनिये ॥ ० ॥

इ हान्बयमुखेनैव मर्बे ख्याख्यायते मय।।

नामूलं लिख्यते किघ्चिन्नानपेचितमु चते ॥ $₹ \|$
यत्म मादाव्भल्लीयन्ते मेा हान्धतम सम्क्टाः ॥ ₹ ॥

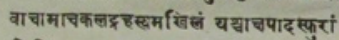

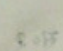

II ग्रीगणोशाय नमः

॥ किरातार्ज्जुनीयम् ॥

$\rightarrow+-$

॥ प्रथमः सर्गा: ॥

श्रियः कुहुण मधिपस्य पालनीं

प्रजास्त वृत्ति यमयुद्त्र वेदितुम् !

से वर्षिलिड़ी विढितः समाययौ।

युधिष्ठिरं द्रैत वने वने चरः ॥ २ ॥

श्रथ तचभवान् भारविनामा कत्रिः काब्यं यशसेडर्थक्हते ब्यव

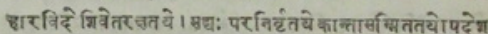
युजे। इत्याद्यालन्रारिकव चनग्रामाख्यात्काव्य खा नेकश्रेय.साधनतां काख्यालापांश वर्ज्नेदिति निषेधभास्त्यासत्कायविषयतास्ष

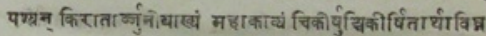

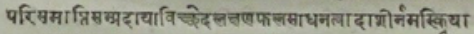
वस्तुरिर्दे शेवापि तन्मुखमित्याद्याजीर्वादाधन्यतकस प्रबन्धमुख

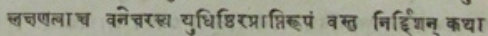

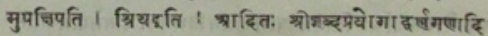
एड्द्रिर बेपययुज्यने। तदुक । देवतावाचका: शब्टा ये च भद्रादि

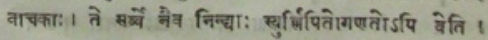

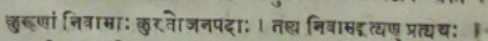
शनपदे लुक्। तेषामधिपस दुर्येंधनस्त्र सम्बन्षिनी। शेषे घही।

क

FIGURE 6.23 Kirātārjunīya, 1847 edition, page 1 (for a complete description, see Appendix C).

With regard to the literature that argues for the revolutionary character of print culture as compared to manuscript or oral culture, one may divide the scholars into two categories: the "Macluhanians" and the "Eisensteinians." The first type focuses more on the psychological impact of the introduction of a new technology on the human mind - in our case, printing - for instance by asking questions about how "the interiorization of media such as letters alter the ratio among our senses and change mental processes" (McLuhan 1962, 24). The second type of scholar is more interested in the economical, cultural, social and even political consequences caused by the introduction of a new technology such as printing, and strives to trace these consequences within their historical and geographic research foci. In what follows, I will try to provide remarks relevant to both these sets of scholarly concerns. 


\subsection{Elizabeth Eisenstein's Agent of Change in South Asia}

In the realm of South Asian book history, it is quite a daunting task to write about any of the influences of the introduction of printing on South Asian history and culture. In fact, the mantra recited by almost all scholars is that the introduction of printing in South Asia on a massive scale happened late, and mostly due to political, economical and Western cultural influence - in other words, it is yet another child of colonialism. Virtually all recent studies on the introduction of printing in South Asia simply highlight that it wasn't introduced on a massive scale before the 1800 s, and leave the question about the reasons of this phenomenon more or less unanswered. If they try to provide an answer, they almost invariably refer to S. Pollock's article Literary Culture and Manuscript Culture in Precolonial India (Pollock 2007), in which he provides a more or less "monogenetic" answer to a rather complex and multi-faceted problem. For instance G. Shaw summarizes the points made by Pollock in his (otherwise) insightful contribution on South Asian book history in A Companion to the History of the Book (Eliot and Rose 2007), although he mitigates Pollock's statement about an "industrial" production of manuscripts by adding the remark that "whether such manuscript production was in fact truly on an 'industrial' scale requires much further research and validation" (Shaw 2007, 130). The "armature" of Pollock's article is fundamental to understanding why, according to him, there is basically a single reason for the absence of the development of a print culture in South Asia before 1800. As Pollock puts it:

In the last several decades scholarship on the invention, diffusion and eventual triumph of print culture has had a considerable impact on the writing of literary, social and even political history. [...] An alternative case could certainly be argued, that the event which was truly historic for literary cultures in India and defined them in the peculiar contours they often still bear, was the invention, diffusion and eventual conquest of manuscript culture, in its specific symbiotic relationship with the antecedent oral culture. The epistemic revolution of literacy, the production of manuscript books (over thirty million manuscripts are still extant), their dissemination in often massively reproduced and relatively stable form and, perhaps most important, their oral performance before large audiences over long periods of time, have had an effect on shaping imagination, sociality and power that is arguably deeper and more extensive than any attributable to print, middle-class book consumption (stunningly low in India), or the culture of private reading reinforced by print (though hardly generated by it). [...] These themes - the interplay 
of the oral and the written; the materiality of manuscript culture; what might be called script-mercantilism - along with the peculiar mix, discernible throughout, of a dynamism that was measured and considered, and a stasis that may have been less a sign of deficiency than a sort of cultural strategy, form the armature of the following survey. (Pollock 2007, 77-78, emphasis mine)

The main reason adduced for the late introduction of print culture in South Asia is what Pollock defines as "script-mercantilism," as opposed to "print-capitalism." According to the American scholar, "script-mercantilism" is a typical feature of South Asian manuscript culture, consisting of its enormous productivity and efficiency, which led to the creation of a huge amount of manuscripts. Pollock states that the "more than thirty million manuscripts estimated still to be extant $[. .$.$] represent the merest fraction of what must once have been pro-$ duced," a figure that compared to the "some thirty thousand manuscripts" still extant "for all of Greek literature, classical, Hellenistic, and Byzantine" means that the Indian manuscripts exceed the Greek ones by a factor of 1000 (2007, 87). First of all, it must be stressed that the figure of thirty million manuscripts does not include only Sanskrit manuscripts, but also manuscripts in vernacular languages, and it is an estimate given by the late Prof. David Pingree based "on a lifetime of academic engagement with Indian manuscripts," and counting "both those [manuscripts] in public and government libraries, and those in private collections," while "the National Mission for Manuscripts in New Delhi works with a conservative figure of seven million manuscripts" (Wujastyk 2014, 159-60). On the other hand, the figure of thirty thousand manuscripts provided by him includes only manuscripts of Greek literature. In fact, if we were to include all manuscripts in Greek, Latin and vernacular languages produced in Europe from the 6th to the 15th century, we would come up with the figure of almost eleven million manuscripts (Buringh and van Zanden 2009, 416, table 1). If we take into consideration these revised estimates of manuscripts production in Europe and South Asia, we notice that the balance is different, and the number of European manuscripts (ca. eleven million) outweighs the number of South Asian manuscripts extant according to the National Mission for Manuscripts (seven million). Apparently, one could argue for the existence of a "script mercantilism" in Europe too, a fact that did not stop the diffusion of a strong print culture. Moreover, in the four cases adduced as instances of "the pre-print publishing industry of south Asia," Pollock addresses only very briefly and superficially some of the characteristic features usually considered to be - rightly or not - a consequence of the "revolution" caused by the printing 
technology. According to E. Eisenstein these characteristics are dissemination, standardization, reorganization, data collection, preservation, and amplification and reinforcement (Eisenstein 1979). For instance, as an example of increased "dissemination" Pollock reports "the story of the production and dissemination of the Sanskrit-Prakrit-Apabhramsha grammar of the Jaina cleric and scholar Hemacandra, the Siddha-Hemacandra-Sabdanusasanam (c. 1140) [...] told in a fourteenth-century collection," relying only on this internal account to demonstrate "the conditions of mass production and the remarkable expanse of the Sanskrit cosmopolitan order within which it circulated," without providing any hard evidence about the number of manuscripts of this work still extant, nor about their codicological features. As to the "standardization" of texts, he refers to what he thinks is "the most remarkable example of religiously motivated, and tightly controlled, text-reproduction in pre-modern India," the diffusion of the Caitanyacaritāmṛta by Kṛ̣nadāsa Kavirāj, a poetic biography of the religious reformer Caitanya in Bengali language, about which he states that "there is none of Eisenstein's 'textual drift' here; print was not the sole bulwark against variation." In order to demonstrate this statement, a few lines later he merely reports the following passage, taken from a work (at that time, still in progress) by Tony Stewart, which actually contradicts Pollock's own statement: "Because of the tight control of Srinivasa in the reproduction of the Caitanya-caritamrta [...] there is decidedly little variation in the manuscripts - a critical edition of the Caitanya-caritamrta would in fact make no sense, because copies are virtually identical, with variation consisting of nothing more than the occasional spelling error, the insertion of paratextual material in the form of chapter/verse citations, or the appending of commentary" (Pollock 2007, 88-89, emphasis mine). In other words, the manuscripts of the Caitanyacaritämrta differed from one another exactly like many other South Asian manuscripts, which differ from each other precisely in terms of layout, presence or absence and typology of paratexts, the correctness and reliability of the language. Moreover, the presence or absence of a commentary is a crucial element: bibliographers, librarians, and readers would consider a printed edition of Vergil's Aeneid with Servius' commentary to be a completely different item than an edition containing Fulgentius' commentary, let alone one with the sole Aeneid. The fact that there is little textual variation in the manuscript tradition of the Caitanyacaritämrta doesn't mean that each and every manuscript of this work is identical.

It is undoubtedly true that print culture in South Asia had two formidable adversaries, oral and manuscript culture. Nevertheless, reasons other than "script mercantilism" might have played a relevant role in the lack of diffusion 
of print in South Asia. A preliminary list might include (1) technical difficulty, (2) religious and cultural taboo, (3) economic inconvenience vis-à-vis manuscript production (including, but not limited to, script-mercantilism), and (4) political control and cultural censorship. In the following section, I will try to discuss some of these points.

As to technical difficulties, there is no reason to suppose that the characters of the various scripts used to represent Sanskrit were obstacles to the spread of printing in South Asia. After all, the printing techniques examined in the present article (xylography, lithography and movable type) were successfully employed, and there is no indication that there was any particular technical difficulty in printing Sanskrit texts in any script. Other technical factors involving the materiality of the book, probably combined with political control and economic inconvenience, might have contributed to the late dissemination of print culture in South Asia. If we look at the emergence and consolidation of print in other Asian regions, we notice that three (if not more) concurrent elements were present: paper technology, Buddhism, and a centralized and strong state structure. As epitomized by the passage of the Aparimitayurjñ $\bar{a}-$ nanāmamahāyannasūtra quoted as an epigraph, the spreading of the Dharma by means of the production and dissemination of books is a central aspect of Buddhism. ${ }^{34}$ It is not by chance that the 1oth century Sanskrit xylographs from Dunhuang contain dhärañis, nor that the Tibetan printed material found in Turfan includes small slips of paper stamped with mantras (as we have seen, the practice of stamping dhäranīs on clay tablets for mass distribution was already known in South Asia in the first half of the first millennium CE). If we look at South Asia, we find a situation different from the one in Central Asia, where paper, woodblock printing and Buddhism were present and widespread simultaneously. In the Indian subcontinent, the writing materials employed in the production of manuscripts were mainly birch-bark, palm-leaf, and paper. Of these three, only paper is suitable for printing, and mass production of paper could be considered a prerequisite for the emergence of print culture. Even if the introduction of paper in South Asia dates to the 12th or 13th century (or even earlier), a significant production of indigenous paper did not start before the 13th-14th century, albeit with different regional patterns: according to K.Janert, a wider use of paper started in northern India from the 13th century, in western India from the 14th century and in eastern India from the 15th century

34 Obviously, the most quoted passage about the Buddhist cult of the book is from the Aștasāhasrikā Prajñāpāramitā, but I think that the centrality of the printing of dhāranīs in Central Asia called for a quote from a maybe less known, yet very widespread text. 
(Janert 1955, 6o). Strikingly, this period coincides with the decline and demise of Buddhism on the Indian subcontinent. In South India, other reasons might have played a role, such as the massive production of palm leaves for manuscripts, which might have rendered pointless the development of centres of paper production, above all if the demand for books was already met by the production of palm-leaf manuscripts. In addition, access to paper and other tools required for printing was often controlled by colonial powers. ${ }^{35} \mathrm{In}$ regions such as Nepal, where there was no colonial presence and paper was produced locally in great quantities and xylography was a known technique used to print Tibetan texts, other reasons may have contributed to the slow emergence of printing - for instance, the desire to maintain the secrecy of Tantric teachings, handed down from master to disciple by means of initiation in a closed lineage. The mistrust of the written word in the form of manuscripts has deep roots in South Asian culture, as witnessed by the very popular, anonymous Sanskrit stanza quoted as an epigraph to this article: "Knowledge stored in a book is [like] money in the hand of others - when the time has come to act, there is neither knowledge nor money." What is print, if not a technique that allows one to store knowledge in even more books, putting this wealth in the hands of even more persons? Unfortunately, we do not yet have enough reliable quantitative data about literacy rates, book markets and manuscript production in South Asia before 1800 to underpin these hypotheses. Nonetheless, an indirect confirmation of the picture presented here is provided by the case of Sri Lanka and Burma, two Buddhist countries where the production of manuscripts on palm-leaf continued well into the 19th century, and the printing technique was first introduced by the colonial powers. Moreover, at the time of annexation by the British, apparently in Burma the literacy rate was higher than in England, even in the absence of a print culture. ${ }^{36}$

\subsection{The Gutenberg Galaxy in the South Asian Sky}

South Asian Sanskrit lithographs as well as Central Asian Sanskrit xylographs share many common features with manuscripts. This fact is usually not taken into consideration, but has fundamental consequences on the alleged impact

35 As pointed out by G. Shaw: "As well as books, Britain was also the source of materials and manpower for printing in South Asia. Types, presses, printers' tools, ink, and particularly paper (as local varieties were found unsuitable for printing) all had to be imported" (Shaw 2007, 132).

36 On the introduction of print in Sri Lanka, see Wolf forthcoming; on Burma, see RuizFalqués forthcoming. 
this new medium has on the mind and attitudes of readers. First of all, the choice of retaining the pothi format (or other manuscript formats, such as the accordion book) and the layout features of manuscripts is striking, all the more because it was not forced. It bears witness to a continuity, not to a change or rupture in book culture, and surely is not an agent of transformation. This phenomenon has been discussed by G. Shaw $(2007,127)$ :

The one printing technology that did strike a cultural chord, particularly with Muslim communities, was lithography, introduced to South Asia in the 1820 s. This was precisely because it enabled the printed book to imitate the characteristics of the manuscript which still held cultural authority. Ironically, it was print that appeared strange and produced problems of legibility in South Asia. This was why as late as the 1830 s Christian missionaries in Orissa paid scribes to copy biblical texts onto palm leaves, a practice begun by the Danish missionaries at Tranquebar in south India in the early eighteenth century - print yielding to the more familiar manuscript letter-forms. But lithography overcame this problem by realizing a paradox: the mass-produced manuscript.

As I have tried to outline above, readers probably experienced no real difference while reading a manuscript, a lithograph or an incunabulum such as the 1814 edition of the Kirātārjunìa. In addition, manuscripts of a work with its commentary might have been even more readable than their printed equivalents, above all if their layout was carefully planned, for instance with lemmata (Skt. pratīka) in the commentary highlighted in red. Obviously, this remark is by no means limited to South Asian manuscripts, nor is it a sort of "layout revolution" limited to printed books, as is sometimes argued. In fact, in European book history this revolution happened almost seven hundred years before Gutenberg:

Around 6oo Irish monks developed a system of writing that separated individual words, which greatly facilitated reading. Finally, around 8oo, modern punctuation, uniform script, and division into paragraphs were introduced, all also greatly helping the reader to understand the text quickly. In sum, a new information technology was created, which, as Ulrich Blum and Leonard Dudley argued, helped launch the European economy in the period that followed.

Blum and Dudley [...] argued that these innovations - and in their view in particular the standardization of Latin in 800 - launched not only the book but a new, uniform, and more efficient form of writing, helping 
to promote European economy in the centuries after ca. 950. (Buringh and van Zanden 2009, 424-25 and 425, fn. 33)

In this case, a change of readers' habits (and possibly of their mental processes) did not occur on account of a change of medium, but on account of a change within the same medium. The divide is not between manuscript and print culture, but between manuscripts in scriptio continua and "marked up" manuscripts: the latter are closer to printed texts than to their manuscript predecessors.

\subsection{Sanskrit Print Culture Reappraised}

Print technology was introduced in South Asia only in the 19th century, having a belated cultural impact. As pointed out by many scholars, in South Asia the interface between the oral and the written word is very important. It is probably for this reason that the interface between the written and the printed word has been neglected, and little attention has been devoted to the aspect of the fixation of languages and texts that printing technology might have introduced. In the case of Sanskrit prints, this aspect has to be examined by closely taking into consideration the type of printing technique employed. As it is usually stressed, each manuscript of a given text is a unique artefact and differs from all other manuscripts of the same text. On the other hand the text of a printed book should be "identical" in all its exemplars (they even share the same errors and flaws). In fact, the reproducibility of a text in virtually countless identical books is almost always adduced as one of the distinctive marks of "print culture" as opposed to "manuscript culture." Strictly speaking, xylographs and lithographs too are printed books. Nevertheless, from a philological point of view, one might be tempted to consider each book printed from a specific wood-block to be an apograph of the manuscript template used. Still, all printed exemplars should be identical. However, this is not always the case, and there are other possibilities which one has to take into account when dealing with xylographs, due to the printing technique, which plays a decisive role in the possibility of changing the text. As $\mathrm{H}$. Eimer has pointed out, instead of a new manuscript, occasionally a template from an old printed book was used to produce a new wood-block. This technique results in the production of "books in which the distribution of the text is exactly identical both within the lines and on the pages, so that one is tempted to consider them as prints from one single woodblock set; yet minimal differences show that these prints were made from different woodblock sets" (translated from Eimer 1980, 196). There are cases in which the differences between the two sets of printed exemplars are minimal, but there are also cases in which the changes are more substantial 
and involve major parts of the text. (All this affects also one of the main features of the printed book, its reproducibility without relevant changes, or in E. Eisenstein's words, the standardization effect of printed texts, as well as their alleged stability.) If we move to another book culture in which xylography was used, we can notice similar patterns. In a recent article, M. Schneider presents the preliminary results of his research on the Selection of Direct Instructions on the Lotus Sütra, a work belonging to a specific genre of Japanese Buddhist commentarial literature, and focuses on the changes occurred during its transmission from manuscripts to xylograph editions. In his study, he examines and compares layout and paratexts (including colophons) of manuscripts and xylographs, outlining the differences in the presentation of the text due to the two different media. Strikingly, he comes to the conclusion that "quite contrary to the by and large faithful copying of the scribes, the publisher [of the xylographs] deleted at places substantial quantities of text while altering others" (Schneider 2011, 81).

In light of these considerations, I would like to pose the following question which might change our approach in relation to studies of the history of the book in Asia: xylographs and lithographs certainly aren't manuscripts, but should we still equate them to books printed with movable types and printing presses? Maybe it would be better to think of them as something similar to a manuscript and a printed book at the same time, and yet different from both.

The Sanskrit xylographs found in Central Asia are also very important as witnesses to the central role Buddhism played in the diffusion of print culture. They were printed under the aegis of the Mongol Yuan dynasty, most probably in the capital city, and not in the small city-states on the Silk Road. It is precisely at this court that other big printing projects were also initiated (such as the printing of Chinese and Tibetan Buddhist canons, as well as of Uighur translations of numerous Buddhist works). In the light of this consideration, the demise and fall of Buddhism in the Indian subcontinent before the successful introduction and diffusion of paper technology seems a very plausible explanation for the late diffusion of print culture in South Asia. As I have stressed above, also other causes might have been decisive, like the colonial powers' control of the technical means for printing, or the distaste of Indian Muslims for the printed books as aesthetically inferior to manuscripts. Complex cultural processes such as the late establishment of a print culture in South Asia can be understood only by taking into consideration their numerous facets. The history of Sanskrit print culture is an integral part of South Asian book history, and hopefully I have demonstrated that it can be of great help in this task. 


\section{Appendices}

The printing process of xylographs and lithographs involves the preparation of a manuscript master copy. These types of printed books thus have a liminal nature, and can be considered to be a sort of bridge between manuscript and printed books. ${ }^{37}$ Accordingly, the description of xylographs in the sHT volumes follows the rules of manuscript description. Only a few selected pieces of information about each xylograph are provided in Appendix A, in the form of a translation from the description in the corresponding SHT volume. Similarly, the description of the lithograph in Appendix B follows the pattern employed in manuscript description. The incunabula are described following a slight modified version of the rules of bibliographical description laid out by Gaskell [1995, 321-6o].

\section{Appendix A: Sanskrit Xylographs from Central Asia}

In order to help readers who wish to check the original complete descriptions, the list is organized according to the sHT volumes. Unless otherwise stated, the fragments are edited in the same sн Sнт $613,614 a, 614$ b, and SH T 5029 have been lost during the transfer after the war and have not been recovered. All xylographs are printed on paper, the size is given in height $\times$ width in centimetres. As to the definitions of the scripts, the policy is to retain the original German names, instead of adding one more layer of confusion by translating them into English. ${ }^{38}$

\section{Volumes 1-4}

\section{SHT 575}

Content: Deśanā, corresponding to Suvarṇaprabhāsottamasūtra III.17-27.

Physical description: 3 folios, accordion-book, $8 \times 13$, 7 lines per folio, one-sided; nordturkistanische Brāhmī, Typ b.

History: Finding location: Qočo, Ruin L (Plan Grünwedel); 1. Turfan expedition.

Bibliography: vOHD vol. X,1 (p. 254); digitized on IDP (the online version of the catalogue entry wrongly describes it as "manuscript, ink on paper").

\section{SHT 580}

Content: Two texts: (a) Catușparișatsūtra (chapter 27f.13-17) and (b) unidentified fragment (mirror image).

37 See for instance Formigatti 2011, 45-48.

38 On the difficulties created in paleographical studies on South Asian scripts by the proliferation of different terms, see Sander 2007. 
Physical description: 2 central parts of folios, accordion-book, (a) $11 \times 28.1,5$ lines per folio, one-sided; (b) $11 \times 16.5,2$ lines per folio, one-sided with a final, page-wide line marking the end of the text; the letters are mirrored and rubbed off on the page; nordturkistanische Brāhmī, Typ b.

History: Finding location: Murtuq, excavation behind ruin 8 in valley 2 of the foothills of Turfan; 3. Turfan expedition.

Bibliography: Waldschmidt; digitized on IDP (the online version of the catalogue entry wrongly describes it as "manuscript, ink on paper").

3. SHT 612 , SHT 1174, SHT $5029^{39}$

SHT 612

Content: Samyuktāgama, six Sūtras from the Parivrājakasaṃyukta:

Kokanada (ff. 157r-159v2),

Anāthapindada (ff. 159v3-162v1),

Dïrghanakha (ff. 162v2-167v1),

Śarabha (ff. 167v2-170v3),

Parivrājaka Sthavira (?) (ff. 170v4-172v2), and

Brāhmaṇasatyāni (ff. 172v3-173r5).

Physical description: 17 left corner fragments, 1 right corner fragment, and 3 fragments; pothī, $10.8 \times 28$ (f. 173); 5 lines per folio, two-sided, single writing frame, string-hole space decorated with a lotus $(15.5 \mathrm{~cm}$ from the left side, interrupting lines $2-4)$.

History: Finding location: Qočo; 1. Turfan expedition.

Bibliography: a) SHT 612: voHD vol. X,1 (p. 270); b) SHT 1174: vOHD vol. X,5 (p. 168f.); c) SHT 5029: VOHD vol. X,10 (p. 70); d); digitized on IDP (ff. 157, 159, 162; the online IDP catalogue entry wrongly describes it as "manuscript, ink on paper").

SHT 1174 (vol. 5)

Content:Fragment of a Sūtra with a text from the Samyuktāgama (Parivrājakasamyukta) Physical description: two parts of one folio, almost fitting together (first fragment $11 \times$ 20,8 , second fragment $9,4 \times 10,5$ ), total dimension of the fragmentary folio ca. $16 \times 32$; 5 lines per folio, two-sided, single writing frame; nordturkistanische Brāhmī, Typ b.

SHT 5029 (vol. 5)

Content: Fragment of a Sūtra with a text from the Samyuktāgama (sūtra 966 in the Chinese version).

39 Since they probably belong to one single xylograph, for the sake of a better understanding a complete description of the SHT 1174 and SHT 5029 is provided immediately after SHT 612 . 
Physical description: a small fragment from the middle of a folio, $4.5 \times 5.5 ; 3$ lines, twosided; nordturkistanische Brāhmī, Typ b.

\section{SHT 613}

Content: Samyuktāgama (corresponding to Sūtra 831-832 in the Chinese version).

Physical description: 1 incomplete folio (fragments from the middle), pothī, 10.6 $\times 26 ; 5$ lines per folio, two-sided; nordturkistanische Brāhmī, Typ b.

History: Finding location: Qočo (bought); 1. Turfan expedition.

Bibliography: voHD vol. X,1 (p. 270-72); voHD vol. X,7 (p. $25^{8}$ suppl.); voHD vol. $\mathrm{x}, 8$ (p. 178 suppl.); digitized on IDP (the online version of the catalogue entry wrongly describes it as "manuscript, ink on paper").

\section{SHт $614 \mathrm{a}$}

Content: Cittānupaśyanā-Smrtyupasthāna.

Physical description: one almost complete folio (folio 13.), unknown format (codex ?), $15 \times 15 ; 5$ lines per folio, two-sided; nordturkistanische Brāhmī, Typ b.

History: Finding location: Qočo, site K (Plan Grünwedel); 1. Turfan expedition.

Bibliography: voH D vol. X,1 (p. 272ff); voHD vol. X,7 (p. 258); Pischel 1904b: 1143 (Publ.) Pischel 1904b: table XI f. (facsimile); digitized on IDP (the online version of the catalogue entry wrongly describes it as "manuscript, ink on paper").

\section{SHT 614b}

Content: Dharmānupaśyanā-Smrtyupasthāna and beginning of the four Samyakprahāna.

Physical description: fragments, unknown format, $10 \times 15 ; 3$ lines per folio, two-sided; nordturkistanische Brāhmī, Typ b.

History: Finding location: Qočo, site K (Plan Grünwedel); 1. Turfan expedition.

Publication: voHD vol. X,1 (p. 272f.); voHD vol. X,7 (p. 258); Pischel 1904b: 1143 (Publ.)

Pischel 1904b: Tafel XIf. (Faksimile); digitized on IDP (the online version of the catalogue entry wrongly describes it as "manuscript, ink on paper").

\section{SHT 627}

Content: unidentified Stotra to the Buddhas.

Physical description: fragments of the left part of a folio; accordion-book(?), $7.4 \times 6.4$; 7 lines per folio, one-sided; nordturkistanische Brāhmī, Typ b (original lost after the moving of the collections due to the war).

History: Finding location: Qočo, site O; 1. Turfan expedition.

Publication: Schlingloff (Buddhistische Stotras aus ostturkistanischen Sanskrittexten, 1955); (the online IDP catalogue entry wrongly describes it as "manuscript, ink on paper"). 


\section{SHT 645}

Content: Śatasāhasrikā Prajñāpāramitā. The following table of contents refers to the extant folios and fragments as described below; the first part is a transcription of the running titles on the left margins, followed by a solution of the abbreviation (commas indicate a new line in the original):

Folios 25-30: śasā (śatasāhasrikā), prajñā (prajñāpāramitāa), ca kha (caturtha khaṇda), pra (prathama);

Folio 81: śa ${ }^{\circ}, \operatorname{pra}^{\circ}$, pra kha ${ }^{\circ}$ (prathama khaṇda), ca (caturtha);

Folios 87-88: śa $^{\circ}, \mathrm{pra}^{\circ}$, dvi kha ${ }^{\circ}$ (dvitīya khaṇda), ca (caturtha);

Folio 200: [pra]jñā $\bar{a}^{\circ}$ ca kha ${ }^{\circ}$ (caturtha khaṇda), dvi (dvitīya); colophon on the verso: ॥ śatasāhasryāḥ prajñāpāramitāyāś caturtha parivarttah \|;

Folio 215: śa ${ }^{\circ}, \operatorname{pra}^{\circ}, \operatorname{tṛ~kha}{ }^{\circ}$ trtīya khaṇda), ca (caturtha);

Folio 230: information only in Chinese;

Folio 245: śa ${ }^{\circ}, \operatorname{pra}^{\circ}$, pra kha ${ }^{\circ}$ prathama khanda), ca (caturtha);

Folio 260: information only in Chinese;

Folios 312v and 313r: information only in Chinese;

One fragment without foliation, but with the running title [pañ] $c \bar{a} v i$ sa in Brāhmī script, suggesting that the fragment belonged rather to a xylograph of the Pañcaviṇśatisāhasrikā Prajñāpāramitā.

Physical description: four complete folios and one almost complete folio, 5 fragments of a left corner, 4 fragments of a right corner, 3 fragments of a left margin, 1 fragment of a right margin, 1 big fragment of an upper margin, 21 small fragments; extant folios no. 25-30, 81, 87-88, 200, 215, 230, 245, 26o, 312, .35; pothī, $16 \times 37$; 6 lines per folio, twosided; on the left margin of each recto and verso, abbreviated running title (including chapter titles) in Pāla script; on the right margin of each recto and verso, part of the chapter number and foliation in Chinese script; Pāla script.

History: Finding location: Qočo, site T I D; 1. Turfan expedition.

Publication: voHD vol. X,1 (p. 289-9o); voнD vol. X,4 (p. 281f.); partially digitized on IDP (the online version of the catalogue entry wrongly describes it as "manuscript, ink on paper").

\section{SHT 646}

\section{Content: Dhäraṇ̄}

Physical description: parts of 2 different folios (probably one left and one right), unknown format (codex?), $10.7 \times 6.5$; 9 lines per folio, two-sided, double frame lines; Pāla script in red ink.

History: Finding location: Qočo; 2. Turfan expedition.

Publication: voHD vol. X,1 (p. 290-91); vOHD vol. X,4 (p. 340 suppl.); digitized on IDP (the online version of the catalogue entry wrongly describes it as "manuscript, ink on paper"). 


\section{Volume 5}

\section{SHT 1105}

Content: recto: Chinese characters; verso: Deśanā (in the anușțbh metre).

Physical description: part of a Chinese scroll, $8.8 \times 12.7$; recto: 5 lines of Chinese handwritten (?) characters; verso: 6 lines printed in nordturkistanische Brāhmī, Typ b. Together with SHT 1924, this fragment belongs to one manuscript. However, in the description of the verso of SHT 1924 it is stated that the Sanskrit text in Brāhmī is written with a calamus, and not printed.

History: Finding location: Sängim; 2. Turfan expedition.

Publication: voHD vol. X,5 (p. 100-1); voHD vol. X,8 (p. 195-6 suppl.); voHD vol. $\mathrm{X}, 5$ (table 43 , facsimile); digitized on ID P (the online version of the catalogue entry wrongly describes it as "manuscript, ink on paper").

\section{SHT 1110}

Content: fragments of an unidentified Mahāyāna text.

Physical description: fragments from the middle of the folio, pothi (?), $13.7 \times 7$; 6 lines per folio, two-sided; nordturkistanische Brāhmī, Typ b.

History: Finding location: Murtuq, site T II; 2. Turfan expedition.

Publication: vo H D vol. X,5 (p. 105, table 45, facsimile); digitized on IDP (the online version of the catalogue entry wrongly describes it as "manuscript, ink on paper").

\section{SHT 1173}

Content: (a) end of a colophon (tas samāptah); (b) verso: parts of the Stanza of Aśvajit (ye dharma formula).

Physical description: two fragments, one from the left side and one from the middle of the folio; accordion book (?), $5 \times 6,1$ line (first fragment), $7 \times 7.8,2$ lines (second fragment); nordturkistanische Brāhmī, Typ b.

History: Finding location: Qočo, site v'; 2. Turfan expedition).

Publication: vo HD vol. X,5 (p. 168, table 7o, facsimile); digitized on IDP (the online version of the catalogue entry wrongly describes it as "manuscript, ink on paper").

\section{SHT 1190}

Content: Sitātapatrahrdayamantra; on the verso, end of the Sitātapatrahrdayamantra (with the title as final rubric), and parts of the Stanza of Aśvajit (ye dharma formula). Physical description: one folio of an accordion book, 9.5 $\times 21.5 ; 5$ lines per folio, double marginal frame lines; nordturkistanische Brāhmī, Typ b.

History: Finding location: Murtuq, site T III M 156; 3. Turfan expedition.

Bibliography: vo HD vol. X,5 (p. 184-85, table 79, facsimile); digitized on IDP (the online version of the catalogue entry wrongly describes it as "manuscript, ink on paper"). 


\section{SHT 1191}

\section{Content: Sarvatathāgatoṣnīṣavijayanāmadhāraṇī}

Physical description: two fragments (upper left corner and a big part of the right side) of one folio, unusual format, $19.7 \times 27.8$; the akșaras are separated by wider blank spaces, giving the impression that each character stands alone; nordturkistanische Brāhmī, Typ b.

History: Finding location; probably Qočo, site T I; 1 . Turfan expedition.

Publication: voHD vol. X,5 (p. 185-86, table 79, facsimile); facsimile on IDP (the online IDP catalogue entry wrongly describes it as "manuscript, ink on paper").

15. SHT $1385^{*}$

Content: probably a Śatasāhasrikā Prajñāpāramitā.

Physical description: one complete damaged folio, pothī, $18.5 \times 57 \cdot 3,6$ lines per folio, two-sided, string hole blank space $7 \mathrm{~cm}$ wide, ca $19 \mathrm{~cm}$ from the left margin and interrupting lines 3-5 and 3-4; nordturkistanische Brāhmī, Typ b.

History: Finding location: Qočo, site T III D III; 3. Turfan expedition.

Publication: voHD vol. X,5 (p. 247-48); *the facsimile on IDP shows a fragment of a manuscript of the Bhikșuṇiprātimokșavibhañga of the Sarvāstivādins; moreover, in voHD vol. X,5 (p. 243f.), this fragment is described as SHT $1358+1385$, but unfortunately at the end of the volume no facsimile is provided.

\section{Volume 6}

16. SHT 1430, SHT 4008, 4015, 4264, 4524b, $4591^{40}$

Content: Vinayavastu: Samghabhedavastu (S BV II: 198.14-199.11). Physical description: a series of fragments belonging to the same folio:

SHT 1430: fragment from the middle of the folio, $7.5 \times 12.8$;

SHT 4008: fragment from the middle of the folio, $4.7 \times 4.5$;

SHT 4015: fragment from the middle of the folio, $4.6 \times 4$;

SHT 4264: fragment from the middle of the folio, $8.7 \times 5.4$;

SHT 4524, 4526b, 4591: numerous small fragments;

faded ruling; nordturkistanische Brāhmī, Typ b.

History: Finding location unknown.

Bibliography: voHD vol. X,6 (p. 132); voHD vol. X,7 (p. 297f. suppl.); voHD vol. X,10 (p. 243f., SHT 4008+4015+4264, Fragm. 1);

40 SHT 1430 was originally identified as a xylograph. Subsequently, it was identified as a manuscript. I believe the first identification is correct (thus, all other fragments should be classified as xylographs). 
Volume 10

17. SHT $435^{2}$

Content: Sarvatathāgatoṣnīṣasitātapatrā Nāma Aparājitā Mahāpratyaingirāa

\section{Mahāvidyārājñ̄}

Physical description: 3 folios of an accordion book, total dimension $29.3 \times 21.8$

(first folio 9.6 × 21.8, second folio $10 \times 21.8$, third folio $9.7 \times 21.8$ ); südturkistanische

Brāhmī (Alphabet v);

History: Finding location: Sängim; 2. Turfan expedition.

Bibliography: voHD vol. X,10 (p. 390-91); Bhattacharya-Haesner et a. 2003: Nr. 94 (facsimile).

Volume 11

18. SHT 4442

Content: fragments of an unidentified text.

Physical description: $p o t h \bar{\imath}$, various fragments:

folio 165 : three fragments, one of the left side of a folio $(16 \times 8.9)$, one from the middle $(16 \times 9.8)$, and one from the right side;

fragment from the middle of a folio $(15.5 \times 8.4)$;

fragment from the middle of a folio $(6.5 \times 7.2)$;

fragment of the upper left corner of a folio $(8 \times 7.9)$;

fragment of the upper margin of a folio $(5.3 \times 15.6)$;

fragment from the middle of a folio $(14 \times 14)$, including a decorated string-hole space; nordturkistanische Brāhmī, Typ b.

History: Finding location: Murtuq, site: (T III M 198); 3. Turfan expedition.

Bibliography: vOHD vol. $\mathrm{X}, 11$.

19. SHT $4465 \mathrm{v}$ )

Content: a small fragment from the upper part of a xylograph, with the frame line on the verso and manuscript pen trials on the recto (four times ma and one time $y a$ ). Physical description: small fragment, $4.2 \times 7$, nordturkistanische Brāhmī, Typ b.

History: Finding location: unknown.

Bibliography: voHDx vol. X,11 (pp. 70-71).

\section{Appendix B. Manuscript and Lithograph of the Śūdrakamalākara Manuscript}

The description of this item has been made on scans of a xerocopy of the original (!), and therefore lacks numerous codicological features. The scans are freely available at https://archive.org/details/Shudrakamalakara. 
Pune, Anandashram Samstha; 124 folios; paper, pothī (height: $10 \mathrm{~cm}$, width: $30 \mathrm{~cm}$ ); Devanāgarī in black ink; foliation: top left margin (under marginal running title).

- Layout: 9-10 lines per page, double marginal frame lines.

- Marginalia: running marginal title $\left(s^{\prime} \bar{u}^{\circ} k a^{\circ}\right)$, top left margin, verso.

- First Rubric: [1vi] śrīgaṇeśāya namaḥ || pāṃduraṃga ||

- Incipit: [1vı] praṇamya rāmaṃ pitarau kamalākaraśarmaṇā || rāmakụṣnatanūjena śūdra[1v2] dharmo nirūpyate || 1 ||

- Explicit: [123v9] yo bhāțțanaṃ agahanārṇavakarṇadhā[124ri]raḥ śāstrāṃtareșu nikhileșv api marmabhettā || yo aśramaḥ kila kṛtaḥ kamalākareṇa prīto [124r2] munāstu sukṛtī budharāmakṛ̣̣naḥ || || ||

- Final rubric: [124r2] iti śrīma‘jjaga'dgurumīmāṃsakanārāyaṇabhaț̣̦asu(!) [124r3]risūnurāmakṛṣnabhaț̣ātmajakamalākarabhațțakṛte śūdradharmatatve śūdrasamasaṃkarajasvarūpaṃ tadvṛ[124r4]ttinirūpạ̣aṃ samāptaṃm、 || \| samāpto yam graṃthạ̣ || || śrīrāmāya namaḥ || ||

- Colophon: [124r5] pūrva[mura.i]vastavyāraghuvaṃśasya pustikā || aparedyuḥ śucir bhūtvā pūjayec ca yathāvidhi || paț̣e vā[124r6]dārupațe(!) vakivale bhūtale pi vā || [[sa]] pūrvaṃ paṃktidvayam kūryāt 4 godhūmaus taṃ̣ulaiḥ śubhaiḥ || prathamā dā[124r7] śasargāṇāṃ [na]vānāṃ tv aparā bhavet || uttarām diśam ārabhya dakṣiṇasyāṃ samāpayet || pūjayet tu kusā[124r8] rītāṃ(!) yāṃ gaurīṃ yāṃ vivekināṃ || triṣu lokeșu yat satyaṃ yat satyaṃ brahmavādiṣu || patin(!) natāsu(!) yat sa[124r9] tyaṃ tat satyam ta[-1-]mastake || ciṃtitaṃ sakalaṃ kāryaṃ paripaśyasi śobhane || tad asmin, śakune brū[124vı] hi kumārī brahmarūpiṇī || prathamaḥ sarga ity ukto dvītī'yo'śakas tathā || tṛtīyaḥ śakunaḥ ślokaḥs taṃ [124v2] vicāryavicakṣaṇaḥ || statiliḍaḥ(?) varjitah ślokaḥ || || || || [124v3] śake 1739 î́varanāmasamuvatsare caitravadyapratipadāṃ saumyavāsare idaṃ pustakaṃ kṛṣnātīraṃsālīgrāmamadhye nirmitam samāptam || || || || || [124v4] bhațtopanāyakagoviṃdabhaț̣ātmajabā kena likhitaṃ || svārthaṃ parārthaṃ ca || pāṃduraṃgaprasan || || [124v5] yādṛśì (!) pustakaṃ dṛșțā tādṛśi (!) likhitaṃ mayā || mūrkhahaste na dātavyaṃ(!) evaṃ vādati pustakaṃ || śrīrāma ||

\section{Lithograph}

- Physical Location: Cambridge University Library, classmark: 834: 1.a.85.44;

- 94 folios; paper, pothī (height: $11.5 \mathrm{~cm}$, width: $32 \mathrm{~cm}$ ); foliation: top left margin (under marginal running title), and bottom right margin, verso.

- Devanāgarī in black ink. Tentatively three different hands can be distinguished: the scribe of folios $2 \mathrm{r}-38 \mathrm{v}$ wrote tall and slender akșaras with $5 \mathrm{~mm}$ height, connecting all characters of a string by means of a continuous upper line, interrupted only by dandas; the akșaras written by the scribe of folios $37 \mathrm{r}-66 \mathrm{v}$ have an height of $4 \mathrm{~mm}$, 
and occasionally the connecting upper line is interrupted; finally, folios $67 \mathrm{r}-74 \mathrm{~V}$ are written by a third scribe, with akșaras having $4 \mathrm{~mm}$ height, but unlike the ones of the first scribe, the ratio between akșara height and width is more even, so that the characters give a more squarish impression.

- Layout: written area height $7.8 \mathrm{~cm}$, width $26.3 \mathrm{~cm}$; 10-11 lines per page; first hand: approximately $5^{0}$ akșaras per line (the variation between the different hands is difficult to assess); akșara height: first hand $5 \mathrm{~mm}$, second hand $4 \mathrm{~mm}$; interlinear space height: $3-4 \mathrm{~mm}$. Pairs of double marginal frame lines. The recto of the first folio consists of a title page imitating wooden covers of manuscripts: on the recto, an illustration reproducing carved floral decorations, in the middle of which the rubric is printed in the following formula: atha śüdrakamalākaraprārambhaḥ; the verso contains a black and white illustration divided in four panels (depicted from left to right: the author of the treatise; figures representing the four varnas in this order: brāhmaṇa, kșatriya, vaiśya, and śüdra). The verso of the last folio is also an imitation of wooden covers: an illustration reproducing carved floral decorations, in the middle of which the final rubric is printed in the following formula: || iti śüdrakamalākarah samāptah $\|$.

- Binding: 19th-century binding. Leather cover with title (Śúdradharmatattwa), date (1861.) and decorative lines in golden letters on the spine; two flyleaves of European paper both at the beginning and the end. In the top left corner of the inside front cover, printed in small characters in black ink: "Bound by Wiseman", and underneath, " 380,1872 ." In the Cambridge University Library collections of Sanskrit manuscripts, many 19th century paper manuscripts in the pothi format have this type of binding by Wiseman.

- Marginalia: running marginal title $\left(s \bar{u}^{\circ} k a^{\circ}\right)$, top left margin, verso.

- First Rubric: [2v1] śrīgaṇeśāya namah [blank space] atha prastāvanā. An introduction in Marathi giving the contents of the work follows.

- Second Rubric: [3v1] śrīgaṇeśāya namahn\|

- Incipit: [3vi] praṇamya rāmaṃ pitarau kamalākaraśarmaṇā || rāmakṛ̣ṇatanūjena śūdradharmo nirūpyate $\|\mathbf{1}\|$

- Explicit: [94v2] yo bhātțanaṃ agahanārṇavakarṇadhāraḥ śāstrāṃtareșu nikhileṣv api marmakṣe[94v3] ttā yo aśramaḥ kila kṛtạ̣ kamalākareṇa prīto munāstu sukṛtī budharāmakṛṣnah \|

- Final rubric: [94r3] iti śrīmajjagadgurumīmāṃsakanārāyaṇabhațtasūrisūnurāma-[94r4]kṛṣnabhațțātmajakamalākarabhaț̣akṛte śnūdradharmatatve śūdrasamasaṃkarajasvarūpaṃ tadvṛttinirūpaṇaṃ samāptaś cāyam nibandhah || || śrīr astu || ||[94r5] śubhaṃ bhavatu || || || || || || || || || || || || ||

- Colophon: [94r6] hem pustaka, vedaśāstrasampanna rājamānya gạ̣eśabāpūjīśāstrī mālavaṇakara āṇi rājaśrī kaulāsavāsī viṣṇubāpūjīśāstrī vāpațayā [94r7] ubhayatāṃnīm bhāgītem chāpaleṃ ase. || śake 1783 durmatināmasaṃvatsare 
|| mārgaśîrșamāsi kṛṣnapakṣe ravivāsare idaṃ pustakaṃ samāptam, || || [94r8] trināgasapteṃdumite śake muṃbākhyapaț̣aṇe || yatnataś ca gạ̣eśena aṃkito yạ̣ śilākṣaraiḥ || 1 || || cha || cha

\section{Appendix C. Incunabula of Bhäravi's Kirātārjunīya with Mallinātha's Commentary (Gaṇțāpatha)}

Published in 1814

Editors: Vidyākaramiśra and Bābū Rāma. Typesetter (printer?): Madanapāla.

Published in Khidirapore (Calcutta) at the Sanskrit Press in 1814 (samskrtayantre khidirapure śrìmadanapālenāinkitam).

[All elements are centered] [Title Page]

|| kāvyanāma || | || kirātārjjunīya || | | [puṣpikā] | | || kavināma || || bhāravi || | | [puṣpikā] \\\|

țīkānāma || | || gaṇțāpatha || | | [puṣpikā] | | || țịkākāranāma || | || mallinātha || | | [puspikā]

[flyleaf ir, Imprint]

|| 1 || \ || atra kāvye sargasaṃkhyā || | așțādaśa 18 || \[puṣpikā] \|| atra kāvye mūlaślokasaṃkhyā || \ekapañcāśadadhikasahasraṃ $105^{2}$ || \[puşpikā] \|| atrārjjunasya kāvyanāyakasya pāśupatāsvalābhaḥ phalam、 || 1 || \[puṣpikā]

[flyleaf iv, Imprint]

|| śāke vaḍagnisaptendusammite vatsare śubhe || || || saake 1736 || \ [separating line] | || candrādrivasubhūmāne vikramādityavatsare || ||| samvvat 1871 || \ [separating line] | || bhūyugmadṛștidharạ̣īsaṃmite yavanābdake || | || san 1221 sāla

|| | [separating line] | || vedabhūmivasucandramāsana.ī savīpramāna || | || māhajūnakevā.isācchapyogranthaparadhāna || | || san, 1814 îsavī | tāḥ 22 jūna || | [puspikā]

[flyleaf ir, Imprint] || 2 \|

[three ślokas] nagare kalikattākhye śrīmallāṭanṛpājñayā | śrī | vidyākaramiśreṇa ${ }^{41}$ bāburāmeṇa dhīmatā || 1 || | sambhūya śodhayitvātha kāvyaṃ țīkāsamanvitam | mu \drākṣareṇa yatnena nyāsitaṃ sudhiyām mude || 2 || | vinā pariśramaṃ dhīrāḥ pāṭhayantu pațhantu ca | tada \rtham an̉kitañ caitat sațīkan̉ kāvyam uttamam 、 || 3 || \[puṣpikā] \|| saṃskṛtayantre khidirapure śrīmadanapālenānikitam、 || \puṣpikā $]$

\section{Published in 1847}

Editors: Tārānātha Tarkavācaspati (1812-1885) et al. (tārānāthatarkkavācaspatibhațțācāryyādivibudhavarair viśodhitam)

41 The type for dya is horrible. 
Published in Calcutta at the Sārasudhānidhi press (kalikātārājadhānyām sārasudhānidhimudrāyantre, 1769 [śake = $1847 \mathrm{CE}$ ]

[Title Page]

[All elements are centered; all puṣpikās are different]

|| kirātārjjunīyam || | [puṣpikā] ||| śrībhāravikṛtam、|| | [puṣpikā] \ sādhāraṇa vidyāvṛddhyarthakasamājādhipatīpsitam 、 | [pușpikā] | śrīmattārānāthatarkkavācaspatibhaț̣ācāryyādivibudhavarair viśodhitam, ${ }^{42} \backslash[$ puṣpikā] \ śrīmaddattavaṃsāāvataṃsaśrīvāvūrasamayadattamahāśayānām ājñayā | kalikātārājadhānyāṃ sārasudhānidhimudrāyantre | mudritam abhūt、 | [puṣpikā] | [stanza in the Sārdūlavikrīẹita meter] angāñgādriśaśānnkasammitaśake ${ }^{43}$ kāvyaṃ kṛtir bhāraver | yantre sārasudhānidhau sulalitam ghaṇṭāpathālañkṛtam、|| | tārānāthadharāmarādivibudhaiḥ śrīlaị̣ śramāc chodhitạ̣ \śrīmaddattakulāgraṇī rasamayādeśād abhūn mudritam, $\| \backslash[$ puṣpikā $] \backslash 1769$

\section{References}

Adduci, M. et al. (eds.). 2011. The Study of Asia between Antiquity and Modernity - A Coffee Break Project, volume LxxxIV, 1.4, Special issue of the Rivista di Studi Orientali. Rome.

Banham, R. 2007. The Industrialization of the Book 1800-1970. In A Companion to the History of the Book, edited by S. Eliot and J. Rose, 273-90. Malden, Mass.; Oxford: Blackwell.

Bendall, C. 1883. Catalogue of the Buddhist Sanskrit Manuscripts in the University Library, Cambridge. With Introductory Notices and Illustrations of the Palcography and Chronology of Nepal and Bengal. Cambridge: University Press.

Buringh, E. and J. L. van Zanden. 2009. Charting the "Rise of the West": Manuscripts and Printed Books in Europe, A Long-Term Perspective from the Sixth through Eighteenth Centuries. The Journal of Economic History 69(2), 409-45.

Chandra, L. 1982. Indian scripts in Tibet, Volume 297 of Śata-pitaka series. New Delhi: Sharada Rani.

Cipolla, C. M. 1969. Literacy and Development in the West. Pelican books. Middlesex: Harmondsworth.

Daniels, P. T. and W. Bright. 1996. The World's Writing Systems. New York: Oxford University Press.

42 The rendering of $o$ in Devanāgari is a good example of the combination of types: the sign for $\bar{a}$ and for $e$ are clearly combined to get a $o$, since there are blank spaces between the different elements. 
Das, S. C. 1888. The Sacred and Ornamental Characters of Tibet. Journal of the Asiatic Society of Bengal $57,41-48$.

Deny, J. (ed.). 1964. Philologiae Turcicae fundamenta: iussu et auctoritate Unionis Universae Studiosorum Rerum Orientalium, auxilio et opera Unitarum Nationum Educationis Scientiae Culturae Ordinis, una cum praestantibus Turcologis, Volume 3. Aquis Mattiacis: Steiner.

Drège, J.-P. 1999. Les premières impressions des dhāraṇī de Mahāpratisarā. Cahiers d'Extrême-Asie 11(1), 25-44.

Eimer, H. 1980. Einige Hinweise zur Edition tibetischer kanonischer Texte: Beobachtungen zur Ueberlieferung in Blockdrucken. Zentralasiatische Studien, 14(1), 195-209. Wiesbaden: Harrassowitz.

Eisenstein, E. L. 1979. The Printing Press as an Agent of Change: Communications and Cultural Transformations in Early-Modern Europe. Cambridge: Cambridge University Press.

2005. The Printing Revolution in Early Modern Europe (2nd ed.). Cambridge: Cambridge University Press.

Eliot, S., A. Nash, and I. R. I. R. Willison. 2007. Literary Cultures and the Material Book. London: British Library.

Eliot, S. and J. Rose. 2007. A Companion to the History of the Book. Blackwell Companions to Literature and Culture 48. Malden, Mass.; Oxford: Blackwell.

Elverskog, J. 1997. Uygur Buddhist Literature. Silk Road Studies 1. Turnhout: Brepols.

Emmerick, R. E. (ed.). 1996. Turfan, Khotan und Dunhuang: Vorträge der Tagung "Annemarie v. Gabain und die Turfanforschung", veranstaltet von der BerlinBrandenburgischen Akademie der Wissenschaften in Berlin (9. 12.12.1994), Volume 1 of Berichte und Abhandlungen / Berlin-Brandenburgische Akademie der Wissenschaften. Berlin: Akademie Verlag.

Formigatti, C. 2011. Manuscript Studies: Crisis on Infinite Methods. In The Study of Asia between Antiquity and Modernity, Volume LxxxIV, 1.4, pp. 43-49. Rome: Rivista degli Studi Orientali.

Gabain, A. v. 1954. Türkische Turfan-Texte VIII. Jahrgang 1952, Nr. 7 in Abhandlungen der Deutschen Akademie der Wissenschaften zu Berlin. Kl. f. Sprachen, Lit. und Kunst. Berlin: Akademie Verlag. 1964. Alttürkische Schreibkultur und Druckerei. In Philologiae Turcicae fundamenta, volume 3. Aquis Mattiacis: Steiner. 1967. Die Drucke der Turfan-Sammlung, Jahrgang 1967 (1) of Sitzungsberichte der Deutschen Akademie der Wissenschaften zu Berlin, Klasse für Sprachen, Literatur und Kunst. Berlin: Akademie-Verlag.

Gardner, K. B. 1993. Descriptive Catalogue of Japanese Books in the British Library Printed Before 1700. London: British Library. 
Gaskell, P. 1995. A New Introduction to Bibliography. New Castle, Delaware: Oak Knoll Press.

Grierson, S. G. A. 1903. The Early Publications of the Serampore Missionaries: A Contribution to Indian Bibliography. Indian Antiquary 32, 241-54.

Hartmann, editor, J.-U. and D. Maue. 1996. Die indisch-türkische Bilingue TT viII G. In Turfan, Khotan und Dunhuang, pp. 147-63. Berlin: Akademie Verlag.

Janert, K. L. 1955. Von der Art und den Mitteln der indischen Textweitergabe: Bericht über mündliche und schriftliche Tradierungsmethoden sowie die Schreibmaterialien in Indien. Köln: Bibliothekar-Lehrinstitut.

Kasai, Y. 2008. Die uigurischen buddhistischen Kolophone. Berliner Turfantexte 26. Turnhout: Brepols.

Kopf, D. 1969. British Orientalism and the Bengal Renaissance: the Dynamics of Indian Modernization, 1773-1835. Berkeley: University of California Press.

Kornicki, P. 2012. The Hyakumantō darani and the Origins of Printing in EighthCentury Japan. International Journal of Asian Studies 9(1), 43-70.

Kāne, P. V. 1930. History of Dharmaśāstra (Ancient and Mediceval Religious and Civil Law). Government Oriental Series 1. Class B. Poona: Bhandarkar Oriental Research Institute.

Lawson, S. D. 1982. A Catalogue of Indian Buddhist Clay Sealings in British Museums. Oxford: Unpublished PhD thesis, Oxford University.

Le Coq, A. v. 1926. Auf Hellas Spuren in Ostturkistan; Berichte und Abenteuer der II. und III. deutschen Turfan-expedition. Leipzig: J. C. Hinrichs.

Maue, D. 1996. Alttürkische Handschriften. Dokumente in Brāhmī und tibetischer Schrift. Verzeichnis der orientalischen Handschriften in Deutschland XIII, 9. Stuttgart: F. Steiner Verlag Wiesbaden.

McLuhan, M. 1962. The Gutenberg Galaxy: the Making of Typographic Man. Toronto: University of Toronto Press.

Mejor, M. 1992. Kșemendra's Bodhisattvâvadānakalpalatā: Studies and Materials. Studia philologica Buddhica / Monograph series 8. Tokyo: International Institute for Buddhist Studies.

Nobel, J. 1937. Suvarṇaprabhāsottamasūtra: Das Goldglanz-Sūtra; ein Sanskrittext des Mahāyāna-Buddhismus. Leipzig: O. Harrassowitz.

Orsini, F. (ed.). 2013. The History of the Book in South Asia. Farnham: Ashgate.

Petech, L. 1984. Mediaeval History of Nepal (2., thoroughly rev. ed. ed.). Serie orientale Roma. Roma: Ist. Ital. per il Medio ed Estremo Oriente.

Pollock, S. 2007. Literary Culture and Manuscript Culture in Precolonial India. In Literary Cultures and the Material Book, pp. 77-94. London.

Preisendanz, K. 2007. Expanding and Merging Horizons. Contributions to South Asian and Cross-Cultural Studies in Commemoration of Wilhelm Halbfass. Beiträge zur 
Kultur und Geistesgeschichte Asiens 53. Vienna: Austrian Academy of Sciences Press.

Quenzer, J., D. Bondarev, and J.-U. Sobisch (eds.). 2014. Manuscript Cultures: Mapping the Field. Studies in Manuscript Cultures 1. Berlin: de Gruyter.

Rocher, R. and L. Rocher. 2012. The Making of Western Indology: Henry Thomas Colebrooke and the East India Company. Milton Park, Abingdon, Oxon; New York: Routledge.

Ruiz-Falqués, A. Forthcoming. Notes on Printing Press and Pali Literature in Burma. Kervan International Journal of Afro-Asiatic Studies. http://www.kervan.unito.it/ contents/presentEN.html Forthcoming.

Sander, L. 1968. Paläographisches zu den Sanskrithandschriften der Berliner Turfansammlung. Verzeichnis der orientalischen Handschriften in Deutschland, Supplementband 8. Wiesbaden: F. Steiner.

2007. Confusion of Terms and Terms of Confusion in Indian Palaeography. In Expanding and Merging Horizons, pp. 121-139. Vienna: Austrian Academy of Sciences Press.

Schlingloff, D. 1955. Buddhistische Stotras aus ostturkistanischen Sanskrittexten. Sanskrittexte aus den Turfanfunden 22. Berlin: Akademie-Verlag.

Schneider, M. 2011. The Difference Engine: Manuscripts, Media Change and Transmission of Knowledge in Premodern Japan. In The Study of Asia between Antiquity and Modernity, pp. 67-83. Rome: Rivista degli Studi Orientali.

Segre, C. 2014. Opera critica (1st ed.). I meridiani. Milano: Mondadori.

Shaw, G. W. 1981. Printing in Calcutta to 180o: a Description and Checklist of Printing in Late 18th-Century Calcutta. London: Bibliographical Society. 1987. The South Asia and Burma Retrospective Bibliography (SABREB). London: British Library.

1993. Lithography v. Letter-press in India. Part I: Lithography in Bombay. South Asia Library Notes \& Queries 29, 1-11.

1998. Calcutta: Birthplace of the Indian Lithography. Journal of the Printing Historical Society 27, 89-111.

2007. South Asia. In A Companion to the History of the Book, edited by S. Eliot and J. Rose Malden, Mass.; Oxford: Blackwell.

Soymié, M. (ed.) 1984. Contributions aux études de Touen-houang. Vol. 3, volume 135 of Publications de l'École française d'Extrême-Orient. Paris: École française d'Extrême-Orient.

Stark, U. 2007. An Empire of Books: the Naval Kishore Press and the Diffusion of the Printed Word in Colonial India. Ranikhet: Permanent Black, Distributed by Orient Longman. 
Sternbach, L. 1967. Cānakya-nīti-text-tradition = [Cānnakya-nüti-śākhā-samprad āyah] Vol. II Part II. Canakya's six Versions of Maxims, an Attempt to Reconstruct the Ur-Text. Vishveshvaranand Indological Series 29a. Hoshiarpur: Vishveshvaranand Vedic Research Institute.

Straube, M. 2006. Prinz Sudhana und die Kinnarī: eine buddhistische Liebesgeschichte von Kșemendra: Texte, Übersetzung, Studie. Indica et Tibetica 46. Marburg: Indica et Tibetica Verlag.

2009. Studien zur Bodhisattvāvadānakalpalatā: Texte und Quellen der Parallelen zu Haribhatțas Jātakamālā. Veröffentlichungen der Helmuth von GlasenappStiftung 1. Monographien. Wiesbaden: Harrassowitz.

Twitchett, D. C. 1983. Printing and Publishing in Medieval China. New York, N.Y.: Frederic C. Beil.

Walleser, M. 1916. Aparimitāyur-jñāna-nāma-mahāyana-sūtram. Nach einer nepalesischen Sanskrit-Handschrift mit der tibetischen und chinesischen Version herausgegeben und übersetzt von M. Walleser. Vorgelegt von Chr. Bartholomae, volume 12 of Sitzungsberichte der Heidelberger Akademie der Wissenschaften. PhilosophischHistorische Klasse. Heidelberg: C. Winter.

Wang-Toutain, F. 2005. Circulation du savoir entre la Chine, la Mongolie et le Tibet au XVIII $^{\mathrm{e}}$ siècle. Le prince mGon-po skyabs. Études chinoises XXIV, 57-111.

Weissenborn, K. 2012. Buchkunst aus Nālandā: die Aștasāhasrikā Prajñāpāramitā Handschrift in der Royal Asiatic Society London (Ms. Hodgson r) und ihre Stellung in der Pāla-Buchmalerei des 11.12. Jahrhunderts. Wiener Studien zur Tibetologie und Buddhismuskunde 77. Wien: Arbeitskreis für Tibetische und Buddhistische Studien, Universität Wien.

Wolf, A.-K. Forthcoming. Hoisted by their Own Petard. The Emergence of Sri Lankan Buddhist Printing and Counter-Christian Activities. Kervan International Journal of Afro-Asiatic Studies. http://www.kervan.unito.it/contents/presentEN .html Forthcoming.

WU, C.-y. 1984. Quatre manuscrits sanscrits de Touen-houang conservés à la Bibliothèque Nationale de Paris. In Contributions aux études de Touen-houang ous la direction de Michel Soymié, volume 3, pp. 55-75. Paris: École française d'Extrême-Orient.

Wujastyk, D. 2014. Indian Manuscripts. In Manuscript Cultures: Mapping the Field. Studies in Manuscript Cultures 1, pp. 159-181. Berlin: De Gruyter.

Zieme, P. 1981. Bemerkungen zur Datierung uigurischer Blockdrucke. Journal Asiatique 269, 385-99.

1982. Zum uigurischen Tārā-Ekavimíśatistotra. Acta Orientalia Academiae Scientiarum Hungaricae $36,583-87$. 
1989. Zum mehrsprachigen Blockdruck des Tārā-Ekaviṃśatistotra aus der Yuan-Zeit. Altorientalische Forschungen 16, 196-97.

1992. Religion und Gesellschaft im uigurischen Königreich von Qočo: Kolophone und Stifter des alttürkischen buddhistischen Schrifttums aus Zentralasien. Abhandlungen der Rheinisch-Westfälischen Akademie der Wissenschaften 88. Opladen: Westdeutscher Verlag.

2009a. Fragmenta Buddhica Uigurica: ausgewählte Schriften. Studien zur Sprache, Kultur und Geschichte der Türkvölker 7. Berlin: Schwarz.

2009b. Wo wurden die altuigurischen Blockdrucke hergestellt? In Fragmenta Buddhica Uigurica: ausgewählte Schriften. 